\title{
The genetic interaction network of CCW12, a Saccharomyces cerevisiae gene required for cell wall integrity during budding and formation of mating projections
}

Enrico Ragni ${ }^{1,2}$, Heidi Piberger ${ }^{1}$, Christine Neupert ${ }^{3}$, Jesús García-Cantalejo ${ }^{4}$, Laura Popolo ${ }^{2}$, Javier Arroyo ${ }^{5}$, Markus Aebi ${ }^{3}$, Sabine Strahl ${ }^{*}$

\begin{abstract}
Background: Mannoproteins construct the outer cover of the fungal cell wall. The covalently linked cell wall protein Ccw12p is an abundant mannoprotein. It is considered as crucial structural cell wall component since in baker's yeast the lack of CCW12 results in severe cell wall damage and reduced mating efficiency.

Results: In order to explore the function of CCW12, we performed a Synthetic Genetic Analysis (SGA) and identified genes that are essential in the absence of CCW12. The resulting interaction network identified 21 genes involved in cell wall integrity, chitin synthesis, cell polarity, vesicular transport and endocytosis. Among those are PFD1, WHI3, SRN2, PAC10, FEN1 and YDR417C, which have not been related to cell wall integrity before. We correlated our results with genetic interaction networks of genes involved in glucan and chitin synthesis. A core of genes essential to maintain cell integrity in response to cell wall stress was identified. In addition, we performed a large-scale transcriptional analysis and compared the transcriptional changes observed in mutant ccw $12 \Delta$ with transcriptomes from studies investigating responses to constitutive or acute cell wall damage. We identified a set of genes that are highly induced in the majority of the mutants/conditions and are directly related to the cell wall integrity pathway and cell wall compensatory responses. Among those are BCK1, CHS3, EDE1, PFD1, SLT2 and SLA1 that were also identified in the SGA. In contrast, a specific feature of mutant cCW $12 \triangle$ is the transcriptional repression of genes involved in mating. Physiological experiments substantiate this finding. Further, we demonstrate that Ccw12p is present at the cell periphery and highly concentrated at the presumptive budding site, around the bud, at the septum and at the tip of the mating projection.
\end{abstract}

Conclusions: The combination of high throughput screenings, phenotypic analyses and localization studies provides new insight into the function of Ccw12p. A compensatory response, culminating in cell wall remodelling and transport/recycling pathways is required to buffer the loss of CCW12. Moreover, the enrichment of CcW12p in bud, septum and mating projection is consistent with a role of Ccw12p in preserving cell wall integrity at sites of active growth.

The microarray data produced in this analysis have been submitted to NCBI GEO database and GSE22649 record was assigned.

\footnotetext{
* Correspondence: sstrahl@hip.uni-heidelberg.de

${ }^{1}$ University of Heidelberg, Centre for Organismal Studies (COS) Heidelberg,

Cell Chemistry, Im Neuenheimer Feld 360, D-69120 Heidelberg, Germany

Full list of author information is available at the end of the article
} 


\section{Background}

The fungal cell wall is a dynamic structure that acts as a permeability barrier for large molecules and is responsible for osmotic stability and cell shape. In Saccharomyces cerevisiae, the cell wall adds up to $30 \%$ of the total cell dry weight. It is mainly composed of polysaccharides $(85 \%)$ and highly glycosylated mannoproteins (15\%) [1]. The vegetative cell wall has a layered ultrastructure with an inner layer of $\beta-1,3$ - and $\beta-1,6$-glucan and chitin, and an outer layer of mannoproteins. $\beta-1,3-$ glucan is synthesized at the plasma membrane and constitutes the principal cell wall polysaccharide to which other components are cross-linked [2,3]. Chitin is synthesized by plasma membrane chitin synthases (CHS1-3) [4]. It is abundant at the bud neck and the primary septum between mother and daughter cells. In addition, chitin is a minor component of the lateral cell wall. Most of the chitin at the bud neck is linked to non-reducing ends of $\beta-1,3$-glucan, whereas the chitin of the lateral cell wall is mainly attached to $\beta-1,6$-glucan $[4,5]$. Soluble cell wall proteins (SCWs) are non-covalently associated with the carbohydrate meshwork [6]. In addition, Pir proteins (proteins with internal repeats; PIR-CWPs) are covalently linked to $\beta-1,3$-glucan, most likely via ester linkages between the $\gamma$-carboxyl group of glutamate residues, arising from glutamine, and glucose hydroxyl groups $[7,8]$. Moreover, at the outer layer of the $\beta$-1,3-glucan meshwork highly branched $\beta-1,6$-glucan is present to which mannoproteins are linked via a remnant of their glycosylphosphatidylinositol (GPI) anchor (GPI-anchored covalently linked cell wall proteins; GPI-CWPs) [4].

GPI-CWPs are either structural proteins or enzymes involved in cell wall biogenesis. They include the flocculins, the agglutinins, the $C R H$ family, the TIR family, the SED1-SPI1 and GAS families $[9,10]$. Interestingly, the GPI-CWP Ccw12p cannot be assigned to one of these families. Loss of Ccw12p results in reduced growth rate and increased sensitivity to the cell wall perturbing agents Calcofluor White (CW) and Congo Red (CR), suggesting that $\mathrm{Ccw} 12 \mathrm{p}$ is required for maintenance of cell wall stability $[7,11]$. In accordance, the amount of cell wall chitin is significantly increased in $c c w 12 \Delta$ cells, a feature of mutants with defects in cell wall integrity [12]. Electron microscopy of $c c w 12 \Delta$ cells revealed random deposition of cell wall material [11]. Most likely, the additional cell wall substance is reinforcing the inner glucan-chitin layer. Further, mutant $c c w 12 \Delta$ is especially sensitive to the aminoglycoside antibiotic hygromycin B, probably due to enhanced cell wall permeability [13]. Very similar phenotypes have been described for mutants that lack other GPI-CWPs involved in cell wall synthesis and organization. For example, the absence of Crh1p and Crh2p, which are required for the cross-linking of chitin to glucan, induces hypersensitivity to CR and CW [14].

Global transcriptional changes in response to deletion of genes crucial for cell wall biogenesis and remodelling (such as GAS1, FKS1, KRE6 and MNN9), exposure to cell wall perturbing agents (e.g., Zymolyase, $C W$ and $\mathrm{CR}$ ) and hyper-activation of the protein kinase $\mathrm{C}$ (PKC1)-dependent Cell Wall Integrity (CWI) pathway have been characterized [15-18]. These analyses revealed a major role for the CWI pathway in activating a compensatory mechanism to counteract different cell wall stress conditions and to prevent cell lysis $[15,16,19]$. The CWI pathway is activated by the plasma membrane sensor proteins Wsc1-3p, Mid2p and Mtl1p [20,21]. In response to wall perturbations the sensors stimulate exchange activity of the guanine nucleotide exchange factor Rom2p that is recruited to the plasma membrane via phosphatidylinositol 4,5-bisphosphate (PI4,5P2) [22]. Rom2p activates the small GTPase Rho1p that in turn activates among others Pkc1p [23]. Pkc1p turns on a mitogen-activated protein (MAP) kinase cascade consisting of the MAP kinase kinase kinase Bck1p/Slk1p, a pair of redundant MAP kinase kinases (Mkk1p and Mkk2p), and the MAP kinase Mpk1p/Slt2p. Slt2p phosphorylation triggers a number of cellular responses, one of which is the transcriptional activation of a variety of genes that have been implicated in cell wall assembly and structure [23]. Notably, genes involved in chitin biogenesis and cross-linking, GFA1, CHS3 and CRH1, were found to be up-regulated in many cell wall mutants [15]. Compensatory chitin deposition was demonstrated to be a crucial trait during cell wall damages and entirely dependent on the activity of Chs3p [24] and on the proteins controlling its transport and activation, Chs4-7p [25,26].

To learn more about the role of Ccw12p, we determined its sub-cellular localization and performed Synthetic Genetic Analysis (SGA) for mutations leading to growth defects when combined with a CCW12 deletion. In addition, we analysed global transcriptional changes in response to deletion of $C C W 12$. Our findings suggest that both, Ccw12p and the CWI pathway are necessary to ensure cell wall integrity, especially during bud emergence and formation of the mating projection.

\section{Results}

\section{Synthetic genetic interactions detected by mutant} screening in a ccw $12 \Delta$ background

Our previous electron microscopic studies and biochemical analyses of the cell wall of $c c w 12 \Delta$ mutants suggested a crucial structural role for $\mathrm{Ccw} 12 \mathrm{p}$ during vegetative cell growth $[11,12]$. To gain further insight 
into the role of Ccw12p, we screened the Euroscarf collection of yeast mutants for mutations causing a growth defect when combined with a CCW12 deletion.

Haploid deletion mutants in 4869 genes marked by the resistance locus for G418 were robotically arrayed and crossed with a $c c w 12:: n a t^{R}$ strain resistant to nourseothricin. The resulting diploid cells were selected, sporulated, and haploid double mutants scored for growth on medium containing both G418 and nourseothricin (see Methods for details). This selection procedure was performed twice to minimize technical errors and false positives. Double mutants showing no growth or very slow growth phenotypes were selected. We identified 129 mutants with putative genetic interactions with $c c w 12 \Delta$. To verify these interactions, all identified mutant strains were sporulated, double mutant spores were selected and analysed for a synthetic phenotype. In this way, 21 bona fide synthetic interactions of $c c w 12 \Delta$ were confirmed. Nine of these double mutants did not grow (synthetic lethal $=\mathrm{sl}$ ) whereas 12 mutants displayed very slow growth phenotypes (synthetic sick = ss; doubling times $>10 \mathrm{hrs}$ ) (Table 1). Interestingly, 10 of the identified genes (BCK1, BRE5, CHS3, CHS5, CHS7, EDE1, MID2, SHE4, SLA1 and SLT2) have been described previously as $C C W 12$ genetic interactors validating the quality of our screening procedure [27-31]. Moreover, the identification of 11 new interactors underlines the sensitivity of the screening. The 21 candidate genes were arranged into functional categories according to the Saccharomyces Genome Database (SGD):

\section{Cell wall synthesis and regulation}

Three of the identified genes are elements of the CWI pathway: the upstream sensor MID2 (ss), the MAP kinase kinase kinase $B C K 1(\mathrm{sl})$ and the MAP kinase SLT2 (sl). Moreover, downstream targets of CWI pathway involved in chitin deposition were found: CHS3 (ss), a $\mathrm{N}$-acetylglucosamine transferase responsible for chitin synthesis at the bud neck and in the lateral cell wall as well as for chitin deposition in response to cell wall stress; CHS4 (ss), a direct activator of Chs3p activity [32] anchoring Chs3p to the septin ring via Bni4p [33]; CHS5 (sl), a component of the exomer complex involved in the polarized transport of Chs3p in specialized vesicles [34]; and CHS7 (ss), a membrane protein controlling Chs3p export from the ER [35-37]. As a compensatory response, increased accumulation of chitin has been observed in $c c w 12 \Delta$ cells [12]. Moreover, deletion of chitin biosynthesis genes in a $c c w 12 \Delta$ background causes lethality, further proving the essential interconnection of Ccw12p and chitin in cell wall stability. Furthermore, we identified another target of the CWI pathway: MNN10 (sl), a Golgi mannosyltransferase involved in processing of $\mathrm{N}$-linked glycans and septum formation [38,39]. Interestingly, simultaneous deletion of HOG1 and CCW12 resulted in a severe growth defect (ss). This result is consistent with previous findings identifying Hog1p, a MAP kinase involved in osmoregulation, as modulator of the response to cell wall damage [15-17,40,41].

\section{Cell polarity and vesicular transport}

Three genes required for endocytosis and polarization of the secretory pathway, EDE1 (ss) (key endocytic protein involved in a network of interactions with other endocytic proteins), SHE4 (ss) (regulator of myosin function), and SLA1 (sl) show severe synthetic phenotypes in combination with $c c w 12 \triangle$. SLA1 is crucial for NPFXDmediated endocytosis that is required for the function of the CWI pathway sensor Wsc1p, thus connecting endocytosis and cell wall integrity [42]. In addition, five genes involved in cell polarity caused a synthetic phenotype: ARC18 (sl) (motility and integrity of cortical actin patches), SAC6 (sl) (organization and maintenance of the actin cytoskeleton), PFD1 (sl) (biogenesis of actin and alpha- and gamma-tubulin), BRE5 (ss) (vesicular transport between the endoplasmic reticulum and Golgi compartments) and FEN1 (ss) (membrane biogenesis).

\section{Other genes}

Finally, genes belonging to other functional categories were found: WHI3 (ss), a cell size regulator required for passage through START; SRN2 (ss), a component of the endosomal sorting complex required for transport-I (ESCRT-I) which is involved in ubiquitin-dependent sorting of proteins into the endosome; PAC10 (sl), a cochaperone promoting efficient protein folding, and $Y D R 417 C$ (ss), a gene of unknown function potentially coding for a GPI anchored protein.

\section{Phenotypic analysis of individual single mutants in genes identified by SGA}

On the basis of computational analyses of large scale experiments EDE1,SHE4, SLA1 and SAC6 are predicted to be involved in cell wall organization, whereas PFD1, WHI3, SRN2, PAC10, FEN1 and YDR417C are not linked to cell wall synthesis, signalling or compensating mechanisms [43]. To further characterize the latter genes, we assayed CW sensitivity of the corresponding deletion mutant strains. CW interferes with the assembly of compensatory cell wall chitin. Therefore, CW sensitivity is a common feature of mutants with cell wall defects. Cells were spotted on solid rich medium containing $25 \mu \mathrm{g} / \mathrm{ml} \mathrm{CW}$, and incubated for 2 days at $30^{\circ} \mathrm{C}$ (Figure 1A). Due to the previously described phenotype [11], the $c c w 12 \Delta$ mutant was included as a control for growth inhibition. Growth of $p f d 1 \Delta$ and $y d r 417 c \Delta$ was not affected by CW (Figure 1A). In contrast, pac10 whi3 $\Delta$ and fen $1 \Delta$ cells displayed intermediate, and $s r n 2 \Delta$ cells high $C W$ sensitivity. 


\begin{tabular}{|c|c|c|c|c|c|c|c|}
\hline \multirow[t]{2}{*}{ ORF } & \multirow[t]{2}{*}{ Gene } & \multirow[t]{2}{*}{ Description of gene product } & \multirow[t]{2}{*}{ SGA } & \multicolumn{2}{|c|}{ Fold change $^{(a)}$} & \multirow{2}{*}{$\begin{array}{l}\text { Interaction in other cell } \\
\text { wall networks }\end{array}$} & \multirow{2}{*}{$\begin{array}{c}\text { Published } \\
\text { interaction }^{\text {(c) }}\end{array}$} \\
\hline & & & & Array & qRT-PCR & & \\
\hline & & Cell wall synthesis and regulation & & & & & \\
\hline YBL061C & CHS4 & $\begin{array}{l}\text { Activator of Chs3p (chitin synthase IIII), recruits Chs3p to } \\
\text { the bud neck via interaction with Bni } 4 p\end{array}$ & ss & & & FKS1, SMI1, GAS1 & - \\
\hline YBR023C & CHS3 & Chitin synthase III & ss & 2.5 & $3.2 \pm 0.7$ & FKS1, SMI1, GAS1 & {$[27,30]$} \\
\hline YDR245W & MNN10 & Subunit of the Mannan polymerase II complex & sl & & & $\begin{array}{c}\text { CHS3, CHS4, CHS5, CHS6, } \\
\text { CHS7, SMI1 }\end{array}$ & - \\
\hline YHRO3OC & SLT2 & MAP-kinase of the cell integrity pathway & sl & 2.2 & $1.7 \pm 0.1$ & $\begin{array}{c}\text { BNI4, CHS3, CHS4, CHS5, } \\
\text { CHS6, CHS7, FKS1, GAS1, } \\
\text { SMI1 }\end{array}$ & [31] \\
\hline YHR142W & CHST & $\begin{array}{l}\text { Involved in chitin biosynthesis by regulating Chs3p export } \\
\text { from the ER }\end{array}$ & ss & & & FKS1, SMI1, GAS1 & {$[27,30,31]$} \\
\hline YJL095W & $B C K 1$ & MAPKK-kinase of the cell integrity pathway & sl & 2.5 & $2.7 \pm 0.5$ & $\begin{array}{l}\text { BNI4, CHS1, CHS3, CHS4, } \\
\text { CHS5, CHS7, GAS1, SMI1 }\end{array}$ & [31] \\
\hline YLR113W & HOG1 & $\begin{array}{l}\text { Mitogen-activated protein kinase involved in } \\
\text { osmoregulation }\end{array}$ & ss & & & & - \\
\hline YLR330W & CHS5 & $\begin{array}{l}\text { Involved in export of selected proteins, such as chitin } \\
\text { synthase Chs3p, from the Golgi to the plasma membrane }\end{array}$ & sl & & & FKS1, SMI1, GAS1 & {$[27,30]$} \\
\hline \multirow[t]{2}{*}{ YLR332W } & MID2 & Sensor for the PKC1-SLT2 cell wall integrity pathway & SS & & & FKS1, SMI1 & {$[27,29,31]$} \\
\hline & & Cell polarity and vesicular transport & & & & & \\
\hline YBLOOTC & SLA1 & $\begin{array}{l}\text { Cortical actin patch assembly control protein, mutation } \\
\text { affects endocytosis }\end{array}$ & sl & 2.7 & $2.7 \pm 0.1$ & $\begin{array}{c}\text { CHS3, CHS4, CHS5, CHS7, } \\
\text { FKS1, SMI1 }\end{array}$ & [31] \\
\hline YBLO47C & EDE1 & Cortical actin patch protein with a role in endocytosis & ss & 2.6 & $2.7 \pm 0.5$ & $\begin{array}{l}\text { BNI4, CHS3, CHS4, CHS5, } \\
\text { CHS7, FKS1 }\end{array}$ & [31] \\
\hline YCR034W & FEN1 & Involved in fatty acids elongation & ss & & & FKS1 & - \\
\hline YDR129C & SAC6 & $\begin{array}{l}\text { Involved in the organization and maintenance of the } \\
\text { actin cytoskeleton }\end{array}$ & sl & & & CHS3, CHS4, CHS5, CHS7 & - \\
\hline YJL179W & PFD1 & $\begin{array}{l}\text { Involved in the biogenesis of actin and of alpha- and } \\
\text { gamma-tubulin }\end{array}$ & sl & 2.5 & $1.7 \pm 0.4$ & & - \\
\hline YLR370C & ARC18 & $\begin{array}{l}\text { Required for the motility and integrity of cortical actin } \\
\text { patches }\end{array}$ & sl & & & $\begin{array}{c}\text { CHS1, CHS3, CHS4, CHS5, } \\
\text { CHS6 }\end{array}$ & - \\
\hline YNR051C & BRE5 & Activator of Ubp3p that regulates COPII coat assembly & ss & & & $\begin{array}{c}\text { BNI4, CHS3, CHS4, FKS1, } \\
\text { SMI1 }\end{array}$ & [31] \\
\hline \multirow[t]{2}{*}{ YORO35C } & SHE4 & Involved in cortical actin patch assembly and endocytosis & ss & & & CHS3, CHS4, CHS7, FKS1 & [31] \\
\hline & & Other genes & & & & & \\
\hline YLR119W & SRN2 & $\begin{array}{l}\text { Component of the ESCRT-I complex, which is involved in } \\
\text { ubiquitin-dependent sorting of proteins into the } \\
\text { endosome }\end{array}$ & ss & & & & - \\
\hline YNL197C & WHI3 & $\begin{array}{l}\text { Regulates the critical cell size required for passage } \\
\text { through Start }\end{array}$ & SS & & & & - \\
\hline YDR417C & & $\begin{array}{l}\text { Hypothetical protein, potential GPI anchor and secretion } \\
\text { sequence }\end{array}$ & ss & & & & - \\
\hline YGR078C & PAC10 & $\begin{array}{l}\text { Polypeptide } 3 \text { of a Yeast Non-native Actin Binding } \\
\text { Complex }\end{array}$ & sl & & & & - \\
\hline
\end{tabular}

(a) Data correspond to the ratio of expression of ccw12 versus wt calculated as described in "Methods".

(b) $[30,60]$.

(c) Published Genetic Interactions with CCW12.

Moreover, we analysed the CWI pathway in the CW

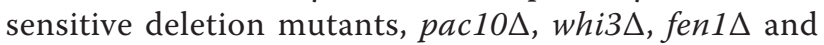
$\operatorname{srn} 2 \Delta$, since constitutive activation of the CWI pathway is a characteristic phenotypic trait of mutants that directly affect cell wall structure. We addressed CWI pathway induction by measuring phosphorylation of the MAP kinase Slt2p. Slt2p activity increases as a result of tyrosine/threonine phosphorylation of the protein.
Protein extracts were analysed by immunoblotting using $\alpha$-phospho-p44/p42 MAP kinase antibodies, which detect the dually-phosphorylated form of Slt2p. The MAP kinase Slt2p was not activated in wild-type (wt) and pac10 , whi3 $\Delta$, fen $1 \Delta$ and $\operatorname{srn} 2 \Delta$ mutant strains under normal growth conditions (Figure 1B). However, cell wall stress conditions (CW treatment and increased temperature) resulted in hyper-activation of Slt2p in the 

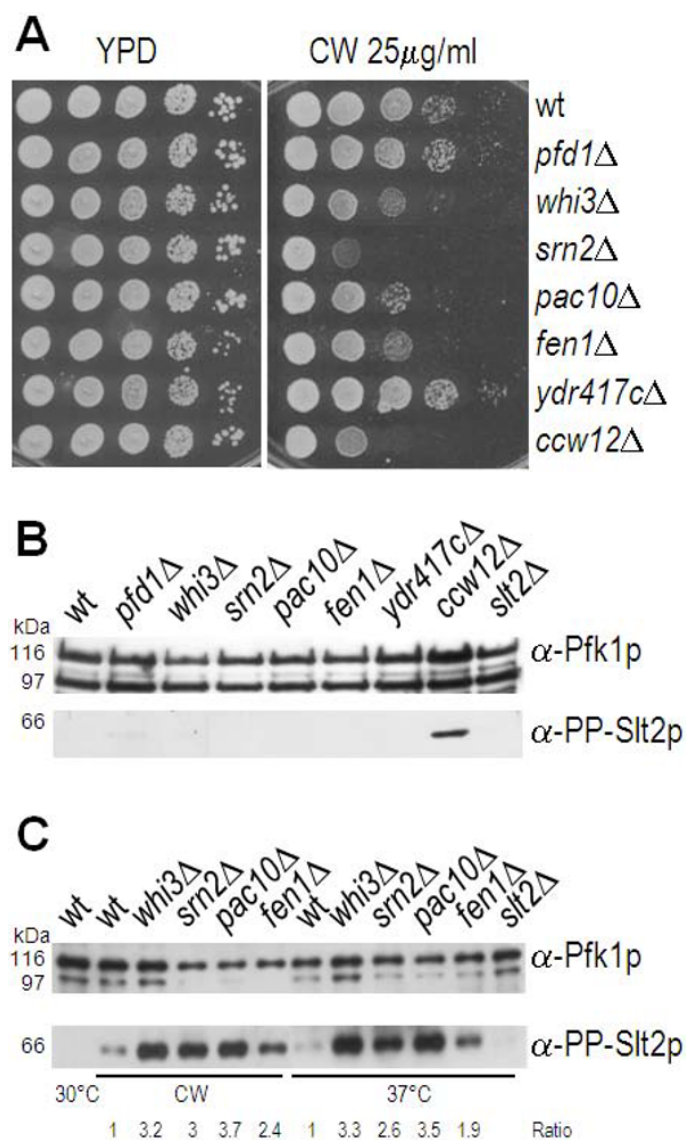

Figure 1 Characterization of individual single mutants in genes identified by SGA. (A) Calcofluor white (CW) sensitivity. Indicated mutant strains were processed as described in Methods. $3 \times 10^{5}$ cells, and 10-fold serial dilutions thereof were spotted on YPD plates with, and without $25 \mathrm{\mu g} / \mathrm{ml}$ of CW. Plates were incubated at $30^{\circ} \mathrm{C}$ for 2 days. (B and $\mathbf{C}$ ) Activation of the CWI pathway. Cell extracts were analysed by Western blot using phospho-p44/p42 MAPK antibodies to detect the dually phosphorylated form of SIt2p, the MAP kinase of the CWI pathway (lower panel, PP-Slt2p). Phosphofructokinase 1 (Pfk1p) was used as a loading control (upper panel, Pfk $1 p$ antibodies are directed against both Pfk1p subunits). (B) To analyse constitutive SIt2p phosphorylation, wt and indicated mutant strains were grown at $30^{\circ} \mathrm{C}$. (C) To analyse induction of Slt2p phosphorylation in response to different stresses, cells were incubated with CW or at elevated temperatures as described in Methods. For unstressed cells, one representative extract is shown. PP-SIt2p and Pfk1p protein levels were quantified using the Scionlmage ${ }^{\mathrm{TM}}$ software, and the amount of PPSIt2p was normalized to the amount of the larger Pfk1 $p$ subunit. Values of the mutants were referred to the wt value (set to 1), and are shown below the figure.

mutants in comparison to wt cells (Figure 1C). Taken together, these results suggest that Pac10p, Srn2p, Whi3p and Fen1p are not directly involved in cell wall assembly but rather affect cell wall stress response. These proteins are involved in crucial processes such as protein folding, sorting into endosomes, cell cycle regulation and membrane lipid synthesis (Table 1). The corresponding mutants display reduced fitness with respect to various stress conditions (e.g., growth at $41^{\circ} \mathrm{C}$; hygromycin B, ethanol treatment; http://www.yeastgenome.org/). Thus, our results suggest that in $p a c 10 \Delta$, whi3 $\Delta$, fen $1 \Delta$ and $\operatorname{srn} 2 \Delta$ cells hyper-activation of the CWI pathway in response to cell wall stress conditions is an indirect effect, although a direct regulation cannot be ruled out completely.

\section{Global transcriptional responses of the $c c w 12 \Delta$ mutant}

In order to comprehensively assess the effect of the cell wall damage caused by $C C W 12$ depletion, we examined the $c c w 12 \Delta$ transcriptome using DNA microarray technology, as described in Methods. Yeast strains were grown to an $\mathrm{OD}_{600}$ of 1 and total RNA was used to analyse expression levels of all $S$. cerevisiae genes present on the Affymetrix GeneChip ${ }^{\circledR}$ Yeast Genome S98 array (Additional file 1).

Deletion of $C C W 12$ resulted in transcriptional changes (fold change $\geq 2$ or $\leq 0.5)$ of 473 genes ( $8 \%$ of the yeast genome) (Additional file 2). Interestingly, 91\% of these genes were up-regulated, while only $9 \%$ showed reduced expression. Among the 431 up-regulated genes, $94 \%$ had 2 to 3 -fold increased transcript levels, and 6\% were more than 4-fold enhanced. In contrast, 41 genes were down-regulated, with $85 \%$ showing a 2 to 3 -fold transcriptional reduction and $15 \%$ being reduced more than 4-fold. Transcriptome data were verified for selected genes using quantitative RT-PCR (qRT-PCR) (Table 1, Table 2 and Table 3) and Northern blot analysis (Additional file 3). Conformity between microarray, qRT-PCR and Northern blot data was obtained for the genes analysed. In the case of ECM13, transcript levels detected by qRT-PCR were less marked, possibly due to different gene regions experimentally verified. However, all experimental approaches point out significant induction of ECM13 transcription in $c c w 12 \Delta$ (Table 2 and Additional file 3).

To further analyse the transcriptional profile of the $c c w 12 \Delta$ mutant, differentially expressed genes were grouped into functional categories according to the MIPS nomenclature (http://mips.helmholtz-muenchen.de). We expressed the number of up- and down-regulated transcripts in each of the categories as percentage of the total number of differentially expressed genes and compared this functional classification with the functional catalogues of genes described in MIPS. As a result the major remodelling of gene expression is accentuated on a genomic scale (Figure 2). Transcripts encoding products involved in central metabolism, generation of energy, cell rescue and biogenesis of cellular components are significantly overrepresented in mutant $c c w 12 \Delta$ (p-value < 0.05; p-values were obtained using hypergeometric distribution statistics; default setting in FunCatDB tools, MIPS). In contrast, transcripts encoding products involved in protein synthesis and transcription 
Table 2 Cell wall related genes modulated in the ccw12 $\Delta$ transcriptional response

\begin{tabular}{|c|c|c|c|c|}
\hline \multirow[t]{2}{*}{$\overline{\mathrm{ORF}}$} & \multirow[t]{2}{*}{ Gene } & \multirow[t]{2}{*}{ Description of gene product } & \multicolumn{2}{|c|}{ Fold change $\mathrm{e}^{(\mathrm{a})}$} \\
\hline & & & Array & qRT-PCF \\
\hline YBLOO1C & ECM15 & Cell wall biogenesis and architecture & 2.2 & \\
\hline YBLO43W & ECM13 & Cell wall biogenesis and architecture & 11.7 & $3.0 \pm 0.9$ \\
\hline YBL101C & ECM21 & Cell wall biogenesis and architecture & 2.4 & \\
\hline YBRO05W & $R C R 1$ & Protein of the ER membrane involved in cell wall chitin deposition & 2.3 & \\
\hline YBR023C & CHS3 & Chitin synthase III & 2.4 & $3.2 \pm 0.7$ \\
\hline YBRO38W & CHS2 & Chitin synthase II & 2.3 & \\
\hline YBR176W & ECM31 & Cell wall biogenesis and architecture & 2.5 & \\
\hline YBR199W & KTR4 & Putative mannosyltransferase & 2.7 & \\
\hline YBR205W & KTR3 & alpha-1,2-mannosyltransferase & 2.2 & \\
\hline YBR229C & ROT2 & Modification of N-linked oligosaccharides & 2.3 & \\
\hline YERO11W & TIR1 & Cell wall mannoprotein & 0.4 & \\
\hline YGLO38C & $\mathrm{OCH} 1$ & Modification of N-linked oligosaccharides & 2.7 & \\
\hline YGL259w & YPS5 & Protein with similarity to GPI-anchored aspartic proteases & 4.4 & $2.6 \pm 0.1$ \\
\hline YHRO3OC & SLT2 & Serine/threonine MAP kinase & 2.2 & $1.7 \pm 0.1$ \\
\hline YIL113w & SDP1 & Dual-specificity MAP kinase phosphatase & 4.4 & \\
\hline YIR019C & MUC1 & GPI-anchored cell surface glycoprotein (flocculin) & 0.4 & \\
\hline YIR039c & YPS6 & Putative GPI-anchored aspartic protease & 4.4 & \\
\hline YJLO95W & $B C K 1$ & Mitogen-activated protein (MAP) kinase kinase kinase & 2.5 & $2.7 \pm 0.5$ \\
\hline YJLO99W & CHS6 & Mediate export of Chs3p from Golgi to PM & 2.9 & \\
\hline YJL128C & PBS2 & MAP kinase kinase of the HOG pathway & 3.7 & \\
\hline YJL139C & YUR1 & Mannosyltransferase of the KTR1 family & 2.4 & \\
\hline YJL174W & KRE9 & beta-1,6 glucan assembly & 2.5 & \\
\hline YJR131W & MNS1 & Alpha-1,2-mannosidase involved in $\mathrm{N}$-linked glycosylation & 2.1 & \\
\hline YJR137C & ECM17 & Cell wall biogenesis and architecture & 3.2 & \\
\hline YKL161C & MLP1 & Putative ser/thr kinase with similarity to SIt2p & 4.4 & $3.5 \pm 0.3$ \\
\hline YKL163W & PIR3 & Cell wall mannoprotein & 3.3 & \\
\hline YKR076w & ECM4 & Cell wall biogenesis and architecture & 3.4 & \\
\hline YLR121C & YPS3 & GPI-anchored aspartic protease 3 & 2.9 & \\
\hline YLR194C & YLR194C & GPI-anchored cell wall protein & 3.2 & \\
\hline YOLOOTC & CSI2 & Structural component of the chitin synthase III complex & 2.3 & \\
\hline YOR382W & FIT2 & GPI-anchored cell wall protein & 3.3 & \\
\hline YPL163C & SVS1 & Cell wall and vacuolar protein & 2.3 & \\
\hline
\end{tabular}

(a) Data correspond to the ratio of expression of $c c w 12$ versus wt calculated as described in "Methods".

Table 3 Mating related genes modulated in the ccw12 $\Delta$ transcriptional response

\begin{tabular}{|c|c|c|c|c|}
\hline \multirow[t]{2}{*}{ ORF } & \multirow[t]{2}{*}{ Gene } & \multirow[t]{2}{*}{ Description of gene product } & \multicolumn{2}{|c|}{ Fold change $^{(a)}$} \\
\hline & & & Array & qRT-PCR \\
\hline YBRO4OW & FIG1 & Integral membrane protein required for efficient mating & 0.4 & $0.3 \pm 0.1$ \\
\hline YCLO27W & FUS1 & Membrane protein localized to the shmoo tip, required for cell fusion & 0.5 & $0.5 \pm 0.1$ \\
\hline YCR089w & $F \mid G 2$ & Cell wall adhesin, expressed specifically during mating & 0.4 & \\
\hline YDLO39C & PRM7 & Pheromone-regulated protein & 0.4 & \\
\hline YGLO89C & MF(ALPHA)2 & Mating pheromone alpha-factor & 0.4 & \\
\hline YIL117C & PRM5 & Pheromone-regulated protein induced during cell integrity signalling & 2.8 & \\
\hline YJL108C & PRM10 & Pheromone-regulated protein & 3.7 & $2.4 \pm 0.2$ \\
\hline YML047C & PRM6 & Pheromone-regulated protein & 0.5 & \\
\hline YNL279w & PRM1 & Pheromone-regulated multispanning membrane protein & 0.4 & \\
\hline YNR044W & AGA1 & Anchorage subunit of a-agglutinin of a-cells & 0.4 & \\
\hline YPL156c & PRM4 & Pheromone-regulated protein & 0.4 & \\
\hline YPL192C & PRM3 & Pheromone-regulated protein & 0.3 & $0.7 \pm 0.2$ \\
\hline
\end{tabular}

(a) Data correspond to the ratio of expression of $c c w 12$ versus wt calculated as described in "Methods". 




Figure 2 Functional categories of the differentially expressed genes. Black bars represent the functional catalogue of 6200 genes according to the MIPS classification. White bars represent the distribution of the 472 differentially expressed genes from $c$ CW $12 \triangle$ mutant according to the MIPS functional catalogue. The percentage of entries is given by the ratio of the number of regulated genes in each category and the total number of differentially expressed genes. Asterisks highlight categories with $p$-values $<0.05$. P-values were obtained using hypergeometric distribution statistics (default setting in FunCatDB tools, MIPS). Note that the sum of entries is more than $100 \%$ since some genes are annotated in more than one functional category in the FunCat database.

were underrepresented (although with a p-value $>0.05$ ), consistent with the fact that cell proliferation is impaired by mutations affecting cell wall biogenesis [44]. At present it cannot be completely excluded that part of the observed responses, especially related to transcription and protein biosynthesis, are due to the reduced growth rate of the $c c w 12 \Delta$ mutant (approximately $25 \%$ less than wt).

Among the differentially expressed genes, 7\% (32 out of 472 genes) are directly involved in the construction and remodelling of the cell wall (Table 2). Most of these genes showed up-regulation while only two, MUC1 and TIR1, have reduced expression. These findings indicate a strong bias towards remodelling of the cell wall in the ccw $12 \Delta$ mutant to compensate for defects. Furthermore, the DNA microarray data revealed that some of the characteristic target genes of the CWI and HOG pathways $[45,18,46]$ were affected in the $c c w 12 \Delta$ mutant. As shown in Table 2, we found regulation of $B C K 1$, coding for the MAPKKK of the pathway; SLT2, the terminal kinase; $M L P 1$, encoding a putative Ser/Thr kinase with similarity to Slt2p; and SDP1, whose product is a dual- specificity MAP kinase phosphatase acting on and regulating the phosphorylated/active form of Slt2p [23]. SLT2 levels increased about 2.2 times, in agreement with a similar modulation reported for other cell wall

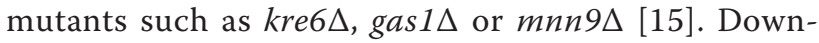
stream targets of the CWI pathway included genes involved in chitin synthesis (RCR1, CSI2, CHS2, CHS3 and CHS6) [47] and $\beta$-1,6-glucan synthesis (KRE9) [48] as well as mannoprotein-encoding genes, such as Pir3p, the putative GPI-anchored Fit2p and Ylr194cp, and GPI-anchored aspartic proteases (yapsines YPS3, YPS5 and YPS6), whose role in the cell wall construction has been inferred from genetic studies [49]. Further, we found transcriptional induction of $P B S 2$, the MAPKK gene of the HOG pathway.

Another group of up-regulated genes is involved in the biosynthesis of protein-linked glycans, including MNS1, which encodes the ER mannosidase I, and ROT2, encoding a luminal $\alpha$-glucosidase II of the ER. Mns1p and Rot2p are involved in the trimming of Nlinked glycans in the ER [50,51]. Similarly, up-regulation was found for OCH1 and YUR1, coding for Golgi $\alpha-1,6$ and $\alpha-1,2$-mannosyltransferases, respectively, both being involved in the maturation of N-linked oligosaccharides [51]; and for KTR3 and KTR4, encoding $\alpha$-1,2-mannosyltransferases involved in the outer chain synthesis of the $\mathrm{N}$-glycans and in the elongation of O-linked oligosaccharides [51].

Beside the alterations in the expression levels of glycosyltransferases and glycosidases, up-regulation of ECM413-15-17-21-31 was observed. These genes encode proteins that are poorly characterized or have unknown functions. However, due to the corresponding mutant phenotypes these genes are thought to play a role in different aspects of cell wall construction.

\section{Comparison of the ccw $12 \Delta$ transcriptome with transcriptional profiles from other cell wall-related mutants}

In order to compare transcriptional changes in the ccw12 12 mutant with transcriptomes from previous studies investigating responses to constitutive cell wall damage caused by deletions of cell wall-related genes, such as GAS1, FKS1, KRE6 and MNN9, and transient cell wall damage induced by $C R$ or Zymolyase treatment $[15,16]$, data were organized by hierarchical clustering (see Methods). As shown in Figure 3, two specific gene clusters could be identified.

Cluster I includes 20 genes that were highly induced in the majority of the mutants/conditions analysed. These genes are directly related to cell wall compensatory responses: the CWI pathway MAP kinase $S L T 2$ and its homolog MLP1 (YKL161c); the known CWI 
pathway downstream targets PRM5; the PIR-CWP PIR3; and four genes coding for GPI-anchored proteins (YLR194c, YPS3, SVS1 and YJL171c). In addition, cluster I includes genes whose absence causes increased stress sensitivity: $F L C 1$, coding for a putative flavin adenine dinucleotide (FAD) transporter required for uptake of FAD into endoplasmic reticulum and cell wall maintenance via disulphide bond formation [52]; $P R Y 2$, encoding a protein of unknown function (null mutant has a decreased resistance to hyperosmotic stress); SUR1, coding for a mannosylinositol phosphorylceramide (MIPC) synthase involved in sphingolipid biosynthesis (null mutant is sensitive to caffeine); FBP26, encoding a fructose-2,6-bisphosphatase (null mutant has a decreased resistance to hyperosmotic stress); and $Y K E 4$, coding for a zinc transporter (null mutant has decreased resistance to CW). Except for SUR1, all of these genes are activated in a strain with hyper-activated PKC1 [53], and thus can be considered as targets of the CWI pathway (Figure 3, right column). Accordingly, promoter analyses of these genes revealed the presence of one or more putative binding sites for the transcription factors of the CWI pathway, RLM1 and/or SWI4 (data not shown).

Cluster II contains genes which are moderately upregulated under most of the analysed conditions (64 genes). Many of them are also induced upon PKC1 overexpression (Figure 3). This cluster includes functional categories like heat shock response and metabolism, comprising 8 genes connected to sugar, glycoside, polyol and carboxylate catabolism (TPS1, ARA1, KGD1, YJR096W, ACO1, IDH1, CIT1 and IDH2) and 6 genes involved in the tricarboxylic-acid pathway (CIT2, KGD1, ACO1, IDH1, CIT1 and IDH2).

To further verify the importance of the CWI pathway for $c c w 12 \Delta$ cells, we analysed the activation of Slt $2 \mathrm{p}$. As positive controls for Slt2p activation, we used cell extracts from gas $1 \Delta$ cells and from wt cells incubated at $37^{\circ} \mathrm{C}$ for three hours. Compared to the wt, the $c c w 12 \Delta$ mutant displayed a 3.85-fold higher level of phosphorylated Slt2p (Figure 4). Addition of $1 \mathrm{M}$ Sorbitol or 0.5 $\mathrm{M} \mathrm{KCl}$ for osmotic stabilization greatly reduced the phosphorylation of Slt2p in $c c w 12 \Delta$ cells.

In summary, loss of CCW12 activates the CWI pathway which in turn up-regulates the expression of a distinct subset of genes that is also induced in all the other cell wall stress conditions analysed so far. Moreover, this pathway ensures cell viability of mutant $c c w 12 \Delta$ as emerged in the SGA screen.

\section{Ccw12p is crucial for cell wall stability of forming daughter cells}

During vegetative growth, the CWI pathway is essential for bud formation [23]. Since $c c w 12 \Delta$ mutants depend on the CWI pathway (see above) and produce buds that are abnormally round [54], we speculated that Ccw12p could play a role in maintaining cell wall integrity during bud growth. Thus, we analysed the mutant for abnormalities during vegetative growth. When grown in YPD medium, buds of $c c w 12 \Delta$ cells appeared rounder when compared to buds of wt cells. Bud morphology was further monitored by determining the relation between the length of the long and short cell axis. In contrast to wt cells (axes ratio of $1.2 \pm 0.1$ ), the long/short axis ratio was diminished in $c c w 12 \Delta$ cells (axes ratio $0.8 \pm 0.1$ ). Furthermore, $16 \%$ of $c c w 12 \Delta$ cells showed cell lysis during bud emergence as compared to only $3 \%$ of wt (Figure $5 \mathrm{~A}$, a and b). Addition of $1 \mathrm{M}$ Sorbitol to the growth medium could partially prevent cell lysis (10\%) and round bud morphology (axes ratio $1.1 \pm 0.1$ ) of $c c w 12 \Delta$ cells (Figure $5 \mathrm{~A}, \mathrm{c})$. Moreover, when $c c w 12 \Delta$ cells were shifted from osmotically stabilized medium (YDP plus $1 \mathrm{M}$ Sorbitol) to YPD (hypotonic shock), buds showed pronounced lysis. While $41 \%$ of the mutant cells underwent cell death mainly in early stages of bud formation, only $8 \%$ of wt cells were affected (Figure 5A, d). To a minor extent, cells lysed after completion of cytokinesis, but, in that case lysis was mainly restricted to daughter cells (Figure 5A, e and $\mathrm{f}$ ).

To further study the role of Ccw12p in bud formation, we analysed its sub-cellular localization. For this purpose we constructed a plasmid encoding a Ccw12p-GFP fusion protein. The GFP-coding sequence was inserted into the $C C W 12-H A$ gene [11] at bp +129 without altering the N-terminal signal sequence and the GPI attachment site. Transcription of GFP fusion was under the control of the endogenous CCW12 promoter. The Ccw12p-GFP fusion protein was completely functional since it was able to complement all described mutant phenotypes, i.e. the slow growth phenotype (wt $\mathrm{T}_{\mathrm{d}}=1.7$ hrs; $c c w 12 \Delta \mathrm{T}_{\mathrm{d}}=2.2 \mathrm{hrs} ; c c w 12 \Delta$ plus Ccw12p-GFP $\mathrm{T}_{\mathrm{d}}=1.8 \mathrm{hrs}$ ) and the CW hyper-sensitivity (data not shown). Fluorescence microscopy revealed a uniform GFP signal around the cell surface confirming the presence of Ccw12p in the plasma membrane/cell wall. Interestingly, Ccw12p-GFP appeared more concentrated at the presumptive budding site on the cell surface of the mother cell shortly before bud emergence (Figure $5 \mathrm{~B}, \mathrm{a})$. Concomitant with bud emergence, Ccw12p-GFP strongly accumulated at the periphery of small to medium-sized buds (Figure 5B, b and c). When buds reached a larger size, the protein appeared in the lateral cell wall of daughter cells and labelled the septum region with an asymmetric localization towards the daughter side. Concurrent with mother/daughter cell separation, Ccw12p-GFP was still detected on the daughter side of the cells (Figure 5B,d). Thereafter, the Ccw12p-GFP signal vanished, suggesting a specific 


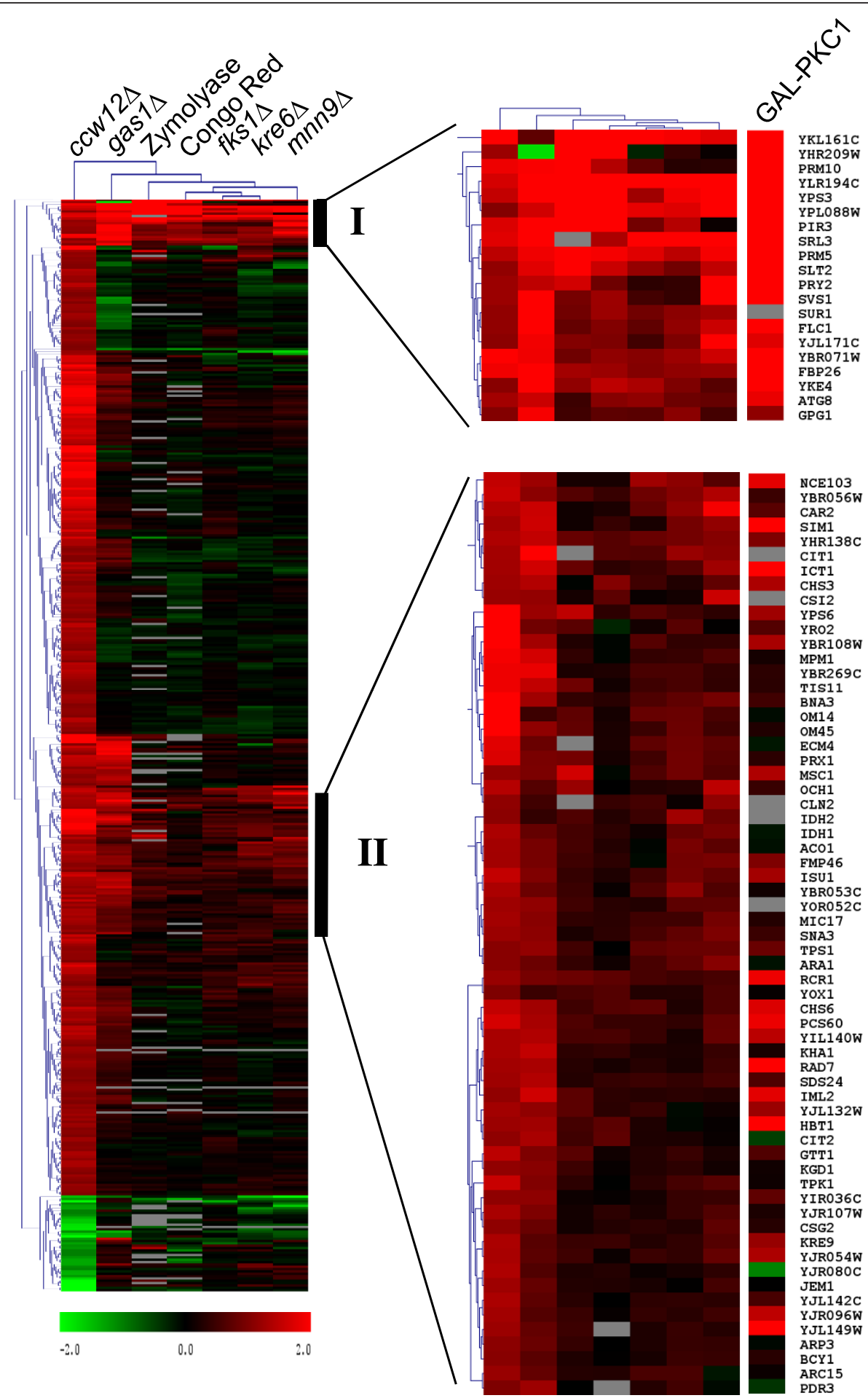

Figure 3 Hierarchical clustering of genes differentially expressed in ccw12 . The transcriptional response of the ccW $12 \Delta$ mutant was compared to transcriptomes of other cell wall mutants (gas $1 \Delta, f k s i \Delta, m n n 9 \Delta$ and $k r e 6 \Delta$ ) and cell wall stress conditions (Zymolyase and Congo Red) $[15,16]$. Each column represents a different condition. Each row represents the ratio of expression for each gene as it is indicated in the colour scale. The clustering tree was built using MeV software from TIGR. 


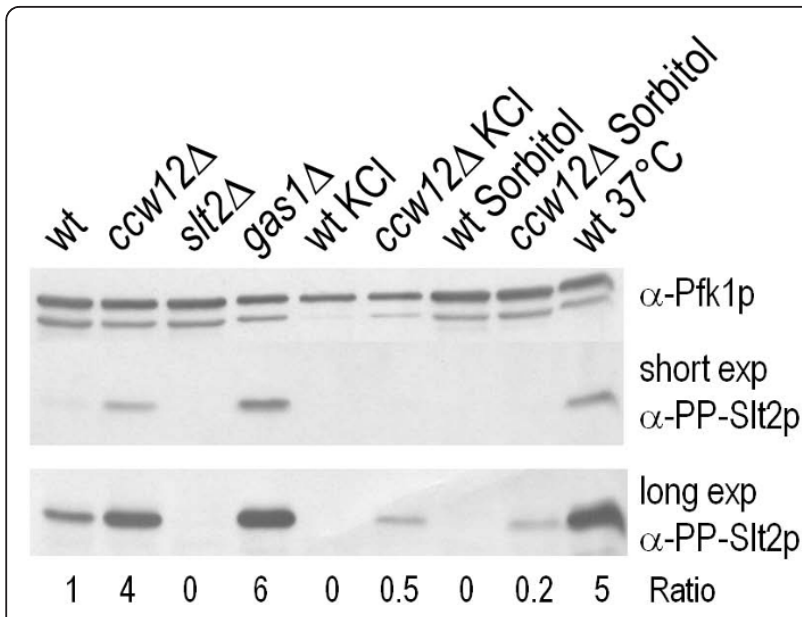

Figure 4 Activation of the CWI pathway in mutant ccw12 Mutant $c C W 12 \Delta$, slt2 $\Delta$, gas $1 \triangle$ and BY4741 (isogenic wt) cells, were grown to mid-exponential phase, and cell extracts were analysed by Western blot using phospho-p44/p42 MAPK antibodies to detect dually phosphorylated SIt2p (mid and low panel, PP-SIt2p). Pfk1p was used as a loading control (upper panel, Pfk1p). PP-Slt2p and Pfk1p protein levels were quantified as described in Figure 1.

function related to the stability of the growing cell wall and the septum. Interestingly, a similar distribution was found for upstream sensors and other components of the CWI pathway, further underlining the crucial role of monitoring correct assembly and structural capacity of the newly synthesized cell wall [55].

In summary, the cell lysis phenotype of $c c w 12 \Delta$ mutants and the localization of Ccw12p-GFP are supporting an essential function of Ccw12p for cell wall integrity predominantly during the formation of daughter cells.

\section{Cow12p is involved in the mating process}

The observed mating and agglutination defects of ccw12 1 mutants indicate a role of CCW12 in conjugation [7]. In accordance with these findings, our transcriptome analysis revealed significant regulation of genes involved in different steps of the mating process (Table 3) and hierarchical cluster analysis further demonstrated that this response is specific for $c c w 12 \Delta$ cells and not observed in other cell wall mutants (data not shown). The gene encoding the mating pheromone $\alpha$-factor, $\operatorname{MF}(A L P H A) 2$, showed a 3 -fold reduction and genes coding for cell wall or plasma membrane proteins involved in mating such as FIG1, FIG2 and FUS1 were down-regulated as well. Further, transcription of a set of pheromone-regulated genes (PRM1-3-4-6-7) required for different steps of membrane and nuclear envelope fusion was reduced. Surprisingly, the pheromone-regulated gene PRM5 was significantly activated (2.84-fold). However, PRM5 is induced by the CWI pathway [18] and thus activation by cell wall stress might overcome the

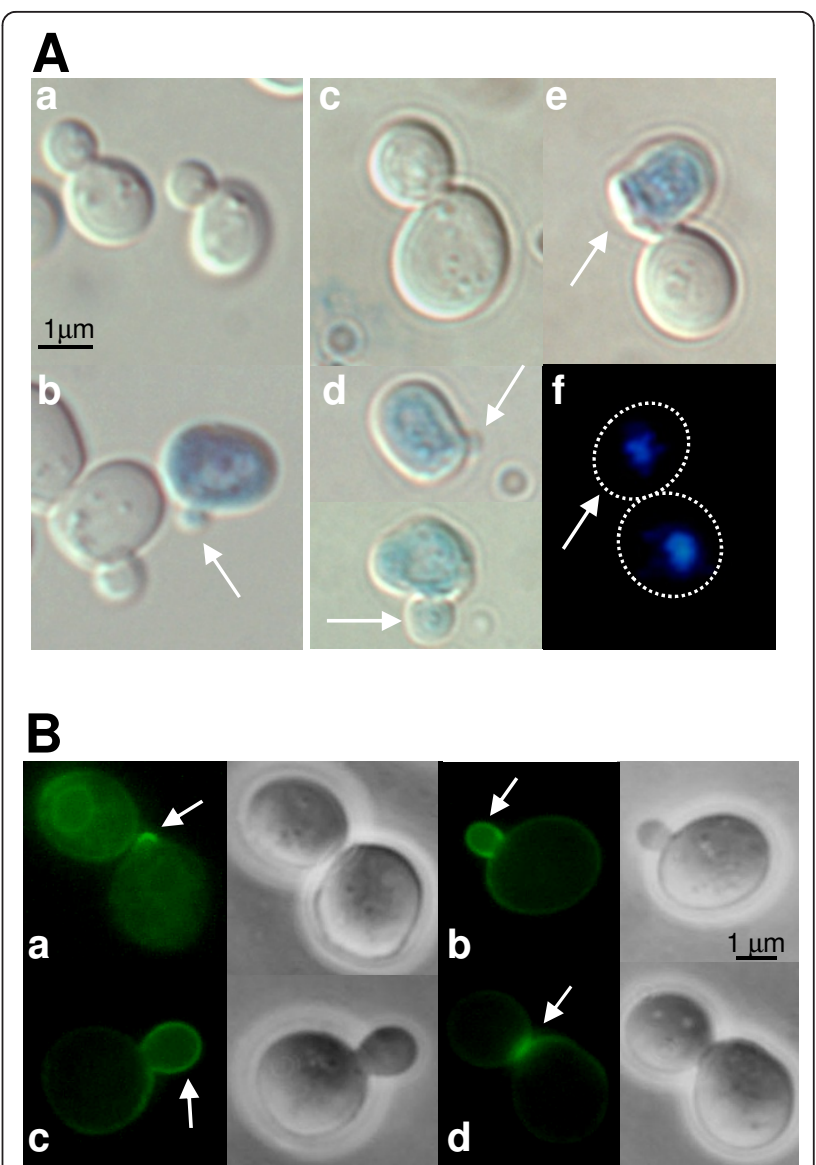

Figure $5 \mathrm{Ccw} 12 \mathrm{p}$ localizes to areas of active cell wall synthesis and $c c w 12 \Delta$ cells display bud lysis. (A) Cell lysis phenotypes. Wt (SEY6211) and cCW12 $\triangle$ mutant (MEY12B) strains, exponentially growing in YPD $(\mathbf{a}, \mathbf{b})$ or YPD supplemented with $1 \mathrm{M}$ sorbitol (c, d), were stained with the vital dye methylene blue to identify dead cells (details are described in Methods): (a) wt cells display a typical ellipsoidal shape; (b) mutant cells show a pronounced round morphology and lyse as small budded cells (16\% of ccw $12 \triangle$ cells vs. $3 \%$ of wt cells); (c) mutant cells round morphology is partially reverted in presence of osmotic stabilization; (d) After hypotonic shock (transfer to YPD) lysis as small budded cell is observed(41\% of ccw $12 \triangle$ cells vs. $8 \%$ of wt cells) and (e-f) cell lysis occurs after completion of cytokinesis as shown by DAPI staining (panel e and $f$ represent the same cells that have been stained with methylene blue and DAPI). (B) Localization of Ccw12p during vegetative growth. To exclude artefacts due to over-expression of CCW12-GFP, Ccw12p-GFP is expressed from plasmid pCCW12-GFP in mutant MEY12B. (a) Ccw12p-GFP is enriched at sites of emerging buds. The arrow marks the site of bud emergence. When cells proceed in the cell cycle, Ccw12p-GFP is specifically enriched in small (b) and medium-sized (c) buds. (d) After cytokinesis Ccw12p-GFP marks the septum.

repression during mating response. Finally, PRM10, that was proposed to be involved in mating, was up-regulated 3.67 fold, possibly due to the presence of one Rlm1p and two Swi4p binding sites in its promoter (data not shown). 
To further substantiate the indicated role of Ccw12p during the mating process, we analysed the response of $c c w 12 \Delta$ cells to mating pheromone. During pheromone treatment, cells arrest in G1 and undergo polarized growth, forming a mating projection that is directed towards the signal source. This chemotropic response is thought to involve the generation of an internal landmark that reflects the direction of incidence of the external pheromone signal and overrides the spatial cues that normally control bud formation [56,57]. Although transcriptome analysis was performed in ccw12 $\triangle$ MATalpha cells, we further characterized the pheromone response of MATa cells since the mating pheromone $\alpha$-factor is commercially available, and for both, ccw12 $\triangle$ MATa and MATalpha cells agglutination and conjugation defects have been demonstrated [7]. However, minor differences cannot be completely excluded. Wt and $c c w 12 \triangle M A T \mathbf{a}$ cells were treated with $20 \mu \mathrm{g} / \mathrm{ml}$ of $\alpha$-factor. Budding index (Figure 6A) and formation of mating projections (shmoos) (Figure 6B) were monitored up to five hours after $\alpha$-factor addition. In wt and $c c w 12 \Delta$ cells the percentage of budded cells decreased from $74 \%$ and $62 \%$, respectively, to $2-3 \%$ after two hours of pheromone treatment. The percentage of budded wt cells remained constant with only a slight increase to $7 \%$ of budded cells after five hours (Figure 6A). Different from that, after 3 hours the number of budded $c c w 12 \Delta$ cells rapidly increased to reach $62 \%$ five hours after $\alpha$-factor addition (Figure 6A) suggesting an earlier release from the $\mathrm{G} 1$ arrest.

Mating projections of $c c w 12 \Delta$ cells were rounder and less polarized than those of wt cells (Figure 7A, a and b). Moreover, methylene-blue vital-staining showed that about $10 \%$ of the $c c w 12 \Delta$ cells undergo mating-induced cell death (versus $1 \%$ of wt cells) (Figure 7A, c). In addition, some shmoo-forming cells are still attached to dead daughter cells (Figure 7A, d-e). Further, $23 \%$ of $c c w 12 \Delta$ mutant cells that are exiting the pheromone block undergo cell lysis during bud emergence (versus $5 \%$ of wt cells) (Figure 7A, f). These data support a role for Ccw12p in stabilizing the cell wall during shmoo formation and during budding upon re-entry into the mitotic cell cycle.

The mating projection is a crucial structure during mating since it serves to concentrate the proteins involved in signalling (pheromones and pheromone receptors), cell adhesion (agglutinins) and fusion (Fus2p) in the area of future cell contact and fusion [58]. Interestingly, components of the CWI pathway, such as the cell wall integrity sensor Mid2p [59], accumulate in the same area suggesting a crucial role for cell wall construction and sensing during this process. Therefore, we used the GFP fusion to monitor Ccw12p localization during $\alpha$-factor treatment. As shown in Figure 7B, Ccw12p-GFP is enriched in mating projections with a

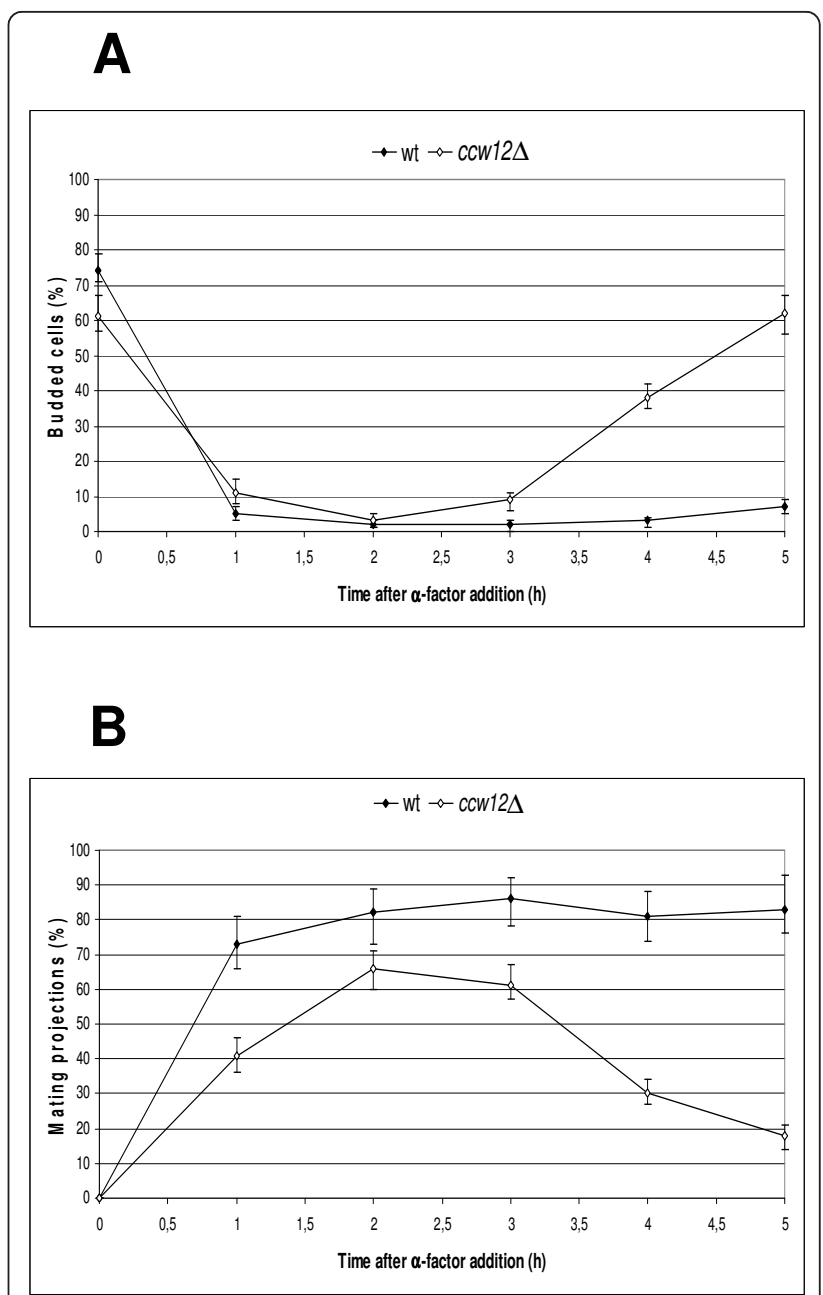

Figure 6 Budding and formation of the mating projection are affected in ccw12 cells. Wt (SEY6211) and cCW12 $\Delta$ mutant (MEY12B) strains were treated with the mating pheromone $\alpha$-factor as detailed in Methods. At time zero $20 \mu \mathrm{g} / \mathrm{ml}$ of $\alpha$-factor were added. Budding index (A) and shmoo formation (B) was monitored over the time. Mean values of four independent experiments are shown. At least 200 cells were analysed at the indicated times.

gradient starting from the tip of the shmoo. The same localization of Ccw12p-GFP was observed when shmoo formation was triggered in MATalpha cells by the presence of MATa cells (data not shown). In combination our data reinforce the notion that Ccw12p plays a general role in cell wall stability at the shmoo apex.

\section{Discussion}

In this work we provide evidence that Ccw12p has a specific role in maintaining the stability of the newly synthesized cell wall especially during bud emergence and formation of the mating projection. Ccw12p localizes to areas of active cell wall synthesis such as forming buds (Figure 5B). In the absence of Ccw12p, buds are abnormally round [54] and cells tend to lyse during bud 

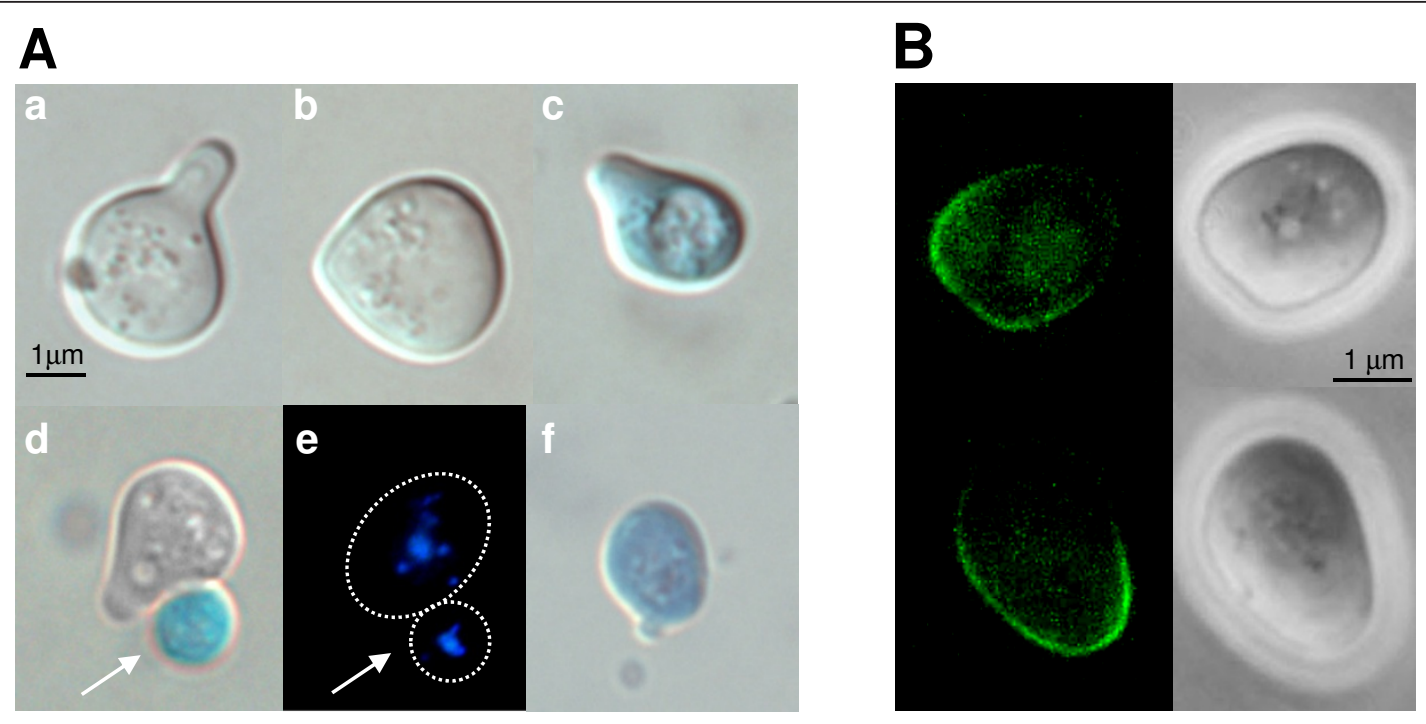

Figure 7 Ccw12p localizes to the shmoo tip and ccw12 cells display pheromone induced cell lysis. (A) Wt (SEY6211) and cCW $12 \Delta$ mutant (MEY12B) strains were treated with $\alpha$-factor $(20 \mu \mathrm{g} / \mathrm{ml})$ for two hours. Cells were stained with the vital dye methylene blue. (a) Wt cells display a typical elongated shmoo. (b) Shmoos of mutant cells are rounder and less polarized. (c) Mutant cells dye during shmoo formation (10\% of ccw $12 \Delta$ vs. $1 \%$ of wt cells). (d, e) Buds of mutants cells released from G1-arrest undergo cell lysis after cytokinesis is completed; a representative cell stained with methylene blue (d) and DAPI (e) is shown. (f) Mutant cells tend to lyse as small budded cells after re-entry of the mitotic cell cycle ( $23 \%$ of ccw $12 \Delta$ vs. $5 \%$ of wt cells). (B) Localization of Ccw12p-GFP to the shmoo during pheromone treatment. Yeast strain described in figure 7B was treated with $\alpha$-factor as indicated in 7A.

emergence and development (Figure $5 \mathrm{~A}$, panel b; $16 \%$ of $c c w 12 \Delta$ vs. $3 \%$ of wt cells). Moreover, when $c c w 12 \Delta$ cells are subjected to hypotonic shock buds lyse more frequently in early stages of development (Figure 5A, panel d; $41 \%$ of $c c w 12 \Delta$ cells vs. $8 \%$ of wt cells). Even after cytokinesis, daughter cells tend to lyse (Figure 5A, panel e). In agreement with the observed lysis phenotype, Ccw12p is specifically localized at the daughter side of the septum (Figure 5B, panel d). During mating, cell lysis is observed when the shmoo is forming (Figure 7A, panel c; $10 \%$ of ccw $12 \Delta$ cells vs. $1 \%$ of wt cells) and Ccw $12 p$ is specifically localized to the mating projection (Figure $7 \mathrm{~B}$ ), further supporting a local function for cell wall stability during remodelling.

The CWI pathway plays a crucial role in cell wall stability especially during bud and shmoo formation. Mutants in this pathway show some of the phenotypic traits that are characteristic for $c c w 12 \Delta$ [23]. We could demonstrate, that in $c c w 12 \Delta$ cells the pathway is hyperactivated (Figure 4) and that osmotic stabilization suppresses CWI pathway hyper-activation (Figure 4) as well as the growth defect of $c c w 12 \Delta$ [12]. In addition, SGA and transcriptome analyses further demonstrate the interdependence between components of the CWI pathway and $C C W 12$ (Tables 1 and 2). SGA revealed synthetic lethality of the CCW12 deletion in combination with mutants of the key regulatory kinases of the CWI pathway, BCK1 and SLT2 (Table 1). In addition, combinatory deletions with chitin synthesis genes (Table 1 ; [60]), and MID2, one of the main sensors of the CWI pathway, (Table 1; [29]) displayed severe synthetic growth phenotypes. Surprisingly, no direct involvement of the sensors WSC1-3 [23] was found. Wsc1p normally localizes to sites of new cell surface growth as similarly observed for Ccw12p-GFP during the budding process. However, we could demonstrate an interaction with SLA1. It is known that Sla1p, a component of the actinand clathrin-based endocytic machinery can serve as an $\operatorname{NPFX}_{(1,2)}$ D-specific endocytic adaptor and that the $\operatorname{NPFX}_{(1,2)}$ D-Sla1p system is responsible for directing Wsc1p into an endocytic and recycling pathway necessary to maintain yeast cell wall polarity [42]. In turn, inhibition of Wsc1p endocytosis causes defects in polarized deposition of cell wall material and increased sensitivity to perturbation of cell wall synthesis. In our analysis, SLA1 deletion conferred synthetic lethality in combination with $c c w 12 \Delta$ (Table 1), similar to what was found in independent screens performed combining deletions of $S L A 1$ and genes involved in glucan and chitin synthesis [60,30]. Moreover, the SLA1 transcript is 2.69-fold increased when CCW12 is absent (Table 1). These results suggest that $\operatorname{NPFX}_{(1,2)} \mathrm{D} / \mathrm{Sla} 1 \mathrm{p}$-mediated endocytosis and polarized localization of Wsc1p are important to ensure cell wall integrity in the developing daughter cell in the absence of Ccw12p. The lack of synthetic lethality of $C C W 12$ in combination with WSC1 
could be explained by a redundant function of one of the other WSC sensors. In contrast, deletion of SLA1 might not only affect WSC1 but other WSC-family members as well.

Transcriptional profiling of the $c c w 12 \Delta$ mutant revealed predominantly cell wall remodelling activities. Members of all categories of cell wall related genes are regulated: CWI pathway signalling, structural components, chitin/glucan synthesis and glycosylation with many of them under the control of PKC1-mediated signalling cascade. Interestingly, despite the high transcriptional activation of some of these genes, their deletion mostly generates mild or no cell wall phenotypes and only a few of them conferred synthetic lethality when deleted in combination with $C C W 12$. This may either be explained by functional redundancy or the need to repress several cell wall functions and/or components in order to cause severe cell wall damage.

In addition to the CWI pathway, the high-osmolarity glycerol (HOG) and the SLN1-SKN7 pathway contribute to cell wall integrity, The HOG pathway is modulated by various plasma membrane sensors [61]. One of which is the kinase $\operatorname{Sln} 1 \mathrm{p}$, the initiating member of a two-component type of phospho-relay cascade that negatively regulates the HOG pathway. In addition, $\operatorname{Sln} 1 \mathrm{p}$ activates the transcription factor Skn7p which in turn triggers the transcription of specific target genes such as $\mathrm{OCH} 1$ and $N C A 3$ [13]. CWI and HOG pathway are closely interconnected suggesting a cooperative role for both pathways controlling cell integrity $[15-17,40,41]$. Likewise, it was suggested that the CWI and the SLN1-SKN7 pathway may function in parallel to protect cells from lysis [13]. Interestingly, SGA revealed the interdependence between $C C W 12$ and HOG1, the MAP kinase of the HOG pathway (Table 1). Further, transcription of $O C H 1$ and $N C A 3$ is significantly increased in the $c c w 12 \Delta$ mutant (2.69- and 3.36fold increase respectively; Additional file 2) confirming previous data that suggested Ccw12p to be a modulator of Sln1p activity [13]. Thus, different signalling pathways are involved to ensure cell wall integrity in the absence of Ccw12p. However, the CWI pathway and cell wall remodelling genes play a dominant role as demonstrated by the preponderance of CWI related genes identified in the SGA screen.

We further addressed the question whether different cell wall defects induce a similar response in yeast cells. Although there is some variation in the regulation of individual genes under different conditions, their functional classification indicates a common principle. We found significant overlap in the transcriptional response to $C C W 12$ deletion as compared to that in other cell wall mutants and treatment with cell wall perturbing agents such as Zymolyase or CR [15,16]. Notably, under all tested conditions we found 20 genes to be strongly induced, which could constitute the core response for cell wall stress (Figure 3, Cluster I). With the exception of SUR1, all the genes in this cluster are CWI pathway targets, reinforcing the notion that survival under cell wall stresses is mediated by different aspects regulated by CWI pathway.

In a previous work, a marked decrease in the mating and agglutination ability of $c c w 12 \Delta$ strain was detected [7]. Here we demonstrate that $c c w 12 \Delta$ cells exhibit diminished $\alpha$-factor sensitivity and earlier release from the pheromone-induced G1 arrest (Figure 6). The mating-related phenotypes could be due to a combination of different factors: i) during pheromone treatment, the absence of Ccw12p at the shmoo apex results in mating induced cell death of $\sim 10 \%$ of the cells (Figure $7 \mathrm{~A}$ ). As a result, mating frequency is significantly reduced. ii) The $c c w 12 \Delta$ expression profile revealed down-regulation of genes involved in the mating process which is not detected in other cell wall mutants. iii) $c c w 12 \Delta$ cells show an early release from the pheromone-induced G1arrest. The time cells display mating projections and the recovery time from pheromone arrest can greatly influence the mating efficiency. It is well known that in the absence of a successful mating event, G1-arrested cells re-enter the mitotic cycle through a recovery process that involves down-regulation of the mating mitogenactivated protein kinase cascade mainly through Msg5p phosphatase activity on the MAP kinase, Fus3p [62]. Furthermore, recovery is regulated by POG1, coding for a putative transcriptional activator [63]. Overexpression of POG1 inhibits $\alpha$-factor-induced G1-arrest and transcriptional repression of the CLN1 and CLN2 genes. This loss of transcriptional repression occurs through $\mathrm{SCB} / \mathrm{MCB}$ promoter elements and requires Bck1p, known to up-regulate Swi4-dependent cell-cycle box (SCB)/MluI cell-cycle box (MCB) promoter elements during vegetative growth [64]. The G1-cyclin Cln2p, in addition to driving the G1- to S-phase transition [65], when over-expressed blocks the ability of cells to arrest in the presence of $\alpha$-factor, primarily through an effect on Ste20p, an activator of the mating MAPK cascade [66]. In agreement with these data, we detected a 3.14fold increase for POG1 and a 2.18-fold increase for $C L N 2$ in $c c w 12 \Delta$ cells, explaining the earlier G1-release.

\section{Conclusions}

Transcriptome and synthetic genetic analyses revealed that in $c c w 12 \Delta$ cells a cell wall compensatory mechanism is activated that integrates several major regulatory systems mainly under control of the CWI pathway-signalling module. Further, we demonstrate for the first time that Ccw12p is mainly localized in areas of newly synthesized cell wall such as emerging buds and mating projections. 
Our data strongly suggest that Ccw12p has a specific role in reinforcing the expanding cell wall. It will be a challenging future task to unravel the molecular mechanism of Ccw12p action.

\section{Methods}

\section{Yeast strains and plasmids}

Standard procedures were used for all DNA manipulations [67]. All cloning and transformations were made in $E$. coli strain DH5a. Oligonucleotide sequences are available upon request.

Plasmid pCCW12-GFP: a 741 bp DNA fragment corresponding to the coding sequence of Aequorea victoria GFP was amplified by PCR and subcloned into the BamHI restriction site of pCCW12 [11]. Correct orientation of the insert was verified by restriction digestion and DNA sequencing.

$S$. cerevisiae strains used in this work are: SEY6210 (MAT $\alpha$ ura3-52 leu2-3,112 his3- $\Delta 200$ trp1- 4901 lys2801 suc2- $\triangle$ GAL [68]); SEY6211 (MATa leu2-3,112 ura352 his3- 200 trp1- 9901 suc2- $\triangle 9$ GAL [68]); MEY12A (SEY6210 except ccw12::URA3 [7]); MEY12B (SEY6211

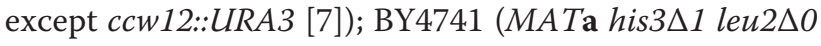
met15 $\Delta 0$ ura3 $\Delta 0$ [69]); $\triangle$ arrayORF (BY4741 except orf $\Delta::$ KanMX4 [69]); Y3656 (MAT $\alpha$ can1 $:: M F A 1 p r-H I S 3-$



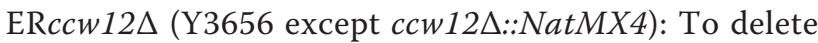
$C C W 12$ in strain Y3656 we used the short-homology PCR technique, followed by one-step gene disruption [70]. Briefly, PCR primers complementary to nucleotides +1 to +60 and +343 to +402 of the CCW12 coding sequence were used to amplify the NatMX4 marker cassette conferring resistance to clonNAT (nourseothricin) from plasmid pAG25. The resulting PCR fragment was transformed into strain Y3656. Correct integration was verified by PCR on genomic DNA.

Yeast cells were grown in synthetic complete (SD) or YPD medium at $30^{\circ} \mathrm{C}$. Haploid deletion mutants were available from the deletion project consortium EUROSCARF. These strains were arrayed in duplicate on fiftyone 384-format plates using a colony picker. Arrays were propagated at $30^{\circ} \mathrm{C}$ on YPD or YPD supplemented with $200 \mu \mathrm{g} / \mathrm{ml} \mathrm{G418} \mathrm{(Invitrogen)} \mathrm{and} 100 \mu \mathrm{g} / \mathrm{ml}$ clonNAT (Werner BioAgents).

\section{SGA screening}

The method described in [27] was used. Briefly, the query strain ERccw $12 \Delta$ was pinned onto a fresh YPD plate at a density of 384 cells per plate. Then, the deletion mutant array was pinned on top of the query cells. The resulting diploids were selected on YPD containing G418 $(200 \mu \mathrm{g} / \mathrm{ml})$ and clonNAT $(100 \mu \mathrm{g} / \mathrm{ml})$. Arrays were then pinned onto sporulation medium. After a 9day incubation at $23^{\circ} \mathrm{C}$ spores were pinned onto haploid selection medium (SD supplemented with histidine, arginine and canavanine) to select for growth of $M A T \alpha$ spore progeny. For 2 days meiotic progenies carrying the G418 resistance locus were selected on medium containing G418 at $30^{\circ} \mathrm{C}$ (SD supplemented with histidine, arginine, canavanine, G418). The G418 and Nat resistant cells were selected on medium containing G418 and clonNAT for 2 days at $30^{\circ} \mathrm{C}$ (SD supplemented with histidine, arginine, canavanine, G418, nourseothricin). Colony size was scored by eye. Each screen was done in duplicate.

To confirm putative interactions spores were diluted in sterile water, spotted onto solid haploid selection medium and incubated for 2 days at $30^{\circ} \mathrm{C}$ (selection of the $M A T \alpha$ progeny). Double mutants were then selected as described above. According to colony growth double mutants were scored as synthetic sick (ss) or synthetic lethal (sl) after 2 days of incubation at $30^{\circ} \mathrm{C}$.

\section{Microarray analysis of differential gene expression}

SEY6210 and ccw12 $\Delta$ (MEY12A) strains were cultured in YPD supplemented with adenine $(39 \mathrm{mg} / \mathrm{l})$ to an $\mathrm{OD}_{600}$ of 1 . Total RNA was extracted according to [71]. For each strain two pools of three independent RNA preparations were obtained, representing two biological replicates each. Concentration of total RNA was measured at $260 \mathrm{~nm}$ and sample quality was checked using RNA Nano Labchips in a Bioanalyzer 2100B (Agilent Technologies, Palo Alto, CA). Double stranded cDNA was synthesized from $5 \mu \mathrm{g}$ of total RNA using "Onecycle cDNA Synthesis Kit" (Affymetrix, Santa Clara, CA). After cDNA purification using the "GeneChip Sample Cleanup Module" (Affymetrix), this DNA was used as template for the in vitro transcription using the "IVT Labeling kit" (Affymetrix) to obtain the biotin labelled cRNA. The obtained cRNA was fragmented and hybridized to the Affymetrix GeneChip ${ }^{\circledR}$ Yeast Genome S98 array for $16 \mathrm{~h}$ at $45^{\circ} \mathrm{C}$. Hybridized microarrays were washed and stained with a streptavidin-phycoerythrin conjugate in a "GeneChip ${ }^{\circledR}$ Fluidics Station 450". All these procedures were carried out as suggested by the manufacturer. Hybridized cRNA was finally identified by the fluorescence signal in a "GeneChip ${ }^{\circledR} 3000$ " scanner. The files generated from the scanning were converted to gene expression signals using the GCOS software (Affymetrix, [72]). Data from the two mutant samples were compared against data from the two SEY6210 samples, obtaining a total of four comparisons. Genes with at least two Present values as "Detection call" and four Increase or Decrease values as "Signal call" were selected for further analysis. The Signal Log Ratio was obtained as the mean of the Signal Log Ratio obtained in each of the four comparisons, and genes with Signal Ratio $>2$ or $<0.5$ were considered for further analysis. Clustering 
and visualization of the data was performed using the MeV software (TIGR) [73].

\section{Quantitative RT-PCR assays}

SEY6210 and $c c w 12 \Delta$ (MEY12A) strains were cultured in YPD supplemented with adenine $(39 \mathrm{mg} / \mathrm{l})$ to an $\mathrm{OD}_{600}$ of 1 . Total RNA was isolated from $5 \times 10^{7}$ cells using the RNeasy MINI kit (mechanical disruption protocol; QIAGEN, Hilden, Germany). On-column DNase digestion of the samples was performed following manufacturer's instructions. From each strain, two biological replicates were processed. Concentration of total RNA was determined by measuring the absorbance at $260 \mathrm{~nm}$. RNA purity and integrity were assessed using the RNA Nano Labchips in an Agilent 2100B Bioanalyzer (Agilent Technologies, Palo Alto, CA). First strand cDNAs were synthesized from $1 \mu \mathrm{g}$ of total RNA in $20 \mu \mathrm{l}$ final volume, using the High Capacity RNA-to-cDNA Master Mix (Applied Biosystems) following the recommendations of the manufacturer. To exclude the presence of genomic DNA, reactions were performed in the absence of reverse transcriptase. Real time quantitative PCR assays were carry out in an ABI 7900HT Fast Real-Time PCR instrument (Applied Biosystems, Foster city, CA) using standard PCR conditions. Duplicates of all reactions were analysed. Quantification of $B C K 1, C H S 3, E C M 13, E D E 1$, FIG1, FUS1, MLP1, PFD1, PRM10, PRM3, SLA1, SLT2, and YPS5 was performed using the "FastStart Universal SYBR Green Master (ROX) (Roche Applied Science)". Based on ORF sequences provided in SGD (http://www. yeastgenome.org/), gene-specific primers were designed using "Primer Express ${ }^{\circledR}$ Software" (Applied Biosystems). Primer sequences will be provided upon request. For quantification, the abundance of each transcript in the mutant was determined relative to the standard $18 \mathrm{~S}$ ribosomal RNA and with respect to the wt by using the Comparative Ct Method. Following this approach, the two RNA samples from the mutant were compared to each of the two samples from the wt strain, thus obtaining a total of four comparisons (four ratios). Final data for each transcript was expressed as a media of these four ratios with their corresponding standard deviation.

\section{Test for Calcofluor white (CW) sensitivity}

Strains were grown in YPD medium to exponential phase. A total of $10^{8}$ cells were collected and suspended in $0.1 \mathrm{ml}$ of sterile water. 10-fold serial dilutions were prepared. $3 \mu \mathrm{l}$ of each dilution were spotted onto YPD plates containing $25 \mu \mathrm{g} / \mathrm{ml} \mathrm{CW}$. After two days of incubation at $30^{\circ} \mathrm{C}$, growth was scored,

Preparation of cell extracts and Western blot analyses Yeast strains were grown in YPD medium to $2 \times 10^{7}$ cells $/ \mathrm{ml}$. In the case of stress induction experiments, log- phase cultures were treated with CW $(40 \mu \mathrm{g} / \mathrm{ml}$ for 1 hour) or exposed to elevated temperature $\left(37^{\circ} \mathrm{C}\right.$ for $\left.3 \mathrm{~h}\right)$. $1 \times 10^{7}$ cells were collected and cell pellets frozen in liquid nitrogen. $20 \mu \mathrm{l}$ of SDS sample buffer $(60 \mathrm{mM}$ Tris$\mathrm{Cl} \mathrm{pH} \mathrm{6.8,2 \%} \mathrm{SDS,} \mathrm{10 \%} \mathrm{glycerol,} \mathrm{5 \%} \beta$-mercaptoethanol, $0.01 \%$ bromophenol blue) were added to the frozen cells. Samples were boiled for $5 \mathrm{~min}$ to extract proteins.

Protein extracts were analysed by SDS-PAGE (8\% PA gels) under reducing conditions and transferred to nitrocellulose. Anti-Phospho-p44/42 MAP Kinase polyclonal antibodies (9101 - Cell Signalling) were used at 1:3,000 dilution; anti-Pfk1p polyclonal antibodies (gift of Prof. Juergen Heinisch) were used at 1:30,000 dilution. Peroxidase-conjugated anti-rabbit secondary antibodies (Jackson Immunoresearch) were used at a 1:10,000 dilution. Protein-antibody complexes were visualized by enhanced chemiluminescence using the GE Healthcare system.

\section{Pheromone treatment}

Exponentially growing yeast cells $\left(5 \times 10^{6}\right.$ cells $/ \mathrm{ml}$ YPD $)$ were treated with $20 \mu \mathrm{g} / \mathrm{ml} \alpha$-factor (GenScript) or mock treated. At indicated times, cells were analysed by phase-contrast microscopy and scored for budding and shmoo formation by counting at least 200 cells after mild sonication.

\section{Fluorescence microscopy}

Yeast strains transformed with plasmid pCCW12-GFP were grown under selective conditions. Cells were collected by centrifugation, washed twice with PBS, and incubated on ice for at least $15 \mathrm{~min}$ before further processing. The cells were examined as wet mounts using a BX60 microscope (Olympus, Melville, NY) and a DC290 digital photo camera (Eastman Kodak, Rochester, NY) or an Eclipse 90i microscope (Nikon, Tokyo, Japan) equipped with epifluorescence, Nomarski optics, and a Hamamatsu ORCA-ER device camera (Nuhsbaum, McHenry, IL). Cell viability was analysed by methylene blue staining [74]. For DNA staining, $8.3 \mu \mathrm{g} / \mathrm{ml} 4,6$-diamidine-phenylindole (DAPI) was used.

To determine cell sizes, differential interference contrast pictures of log-phase cells were taken. The ratio of the length of the long and short cell axis was determined. For average values at least 180 cells per strain were surveyed.

\section{Additional material}

Additional file 1: ccw12 $\Delta$ microarray dataset

Additional file 2: Genes up- and down-regulated in ccw12 $\Delta$ mutant

Additional file 3: Northern blot analysis of ECM13 and PIR3

expression in ccw12 $\Delta$ cells 


\section{Acknowledgements}

We thank J.M Rodriguez-Peña for providing assistance with gRT-PCR experiments and L. Weber for RNA preparation. We are very grateful to M. Buettner for redacting the manuscript. We thank J. Heinisch for generously providing Pfk1p antibodies. J.A. and S.S. acknowledge financial support from the project EU STREP FUNGWALL LSBH-CT-2004-511952; S.S. and E.R. were further supported by the Deutsche Forschungsgemeinschaft (SFB 638); J.A. was supported by BIO2007-67821 and BIO2010-22146 (MICINN, Spain); and L. P. from P.U.R. grants 2009. E.R. is a recipient of a type A contract from Università degli Studi di Milano. S.S. is member of CellNetworks - Cluster of Excellence (EXC81).

\section{Author details}

${ }^{1}$ University of Heidelberg, Centre for Organismal Studies (COS) Heidelberg, Cell Chemistry, Im Neuenheimer Feld 360, D-69120 Heidelberg, Germany. ${ }^{2}$ Università degli Studi di Milano, Dipartimento di Scienze Biomolecolari e Biotecnologie, Via Celoria 26, 20133 Milan, Italy. ${ }^{3}$ ETH Zürich, Institut für Mikrobiologie, Wolfgang-Pauli-Strasse 10, 8093 Zürich, Switzerland. ${ }^{4}$ Unidad de Genómica-Campus Moncloa, Parque Científico de Madrid, Facultad CC. Biológicas, Universidad Complutense de Madrid, 28040 Madrid, Spain. ${ }^{5}$ Departamento de Microbiología II, Facultad de Farmacia, Universidad Complutense de Madrid, 28040 Madrid, Spain.

\section{Authors' contributions}

ER carried out the molecular genetic and physiological studies, participated in the microarray data analyses. HP carried out the microarray experiments, JGC performed the microarray statistical analysis and qRT-PCR; and CN participated in the SGA set up. ER and SS drafted the manuscript. LP, MA, JA and SS conceived the study, and participated in its design and coordination, and helped to draft the manuscript. All authors read and approved the final manuscript.

Received: 26 May 2010 Accepted: 14 February 2011

Published: 14 February 2011

\section{References}

1. Nguyen $T H$, Fleet GH, Rogers PL: Composition of the cell walls of several yeast species. Appl Microbiol Biotechnol 1998, 50:206-212.

2. Smits GJ, Kapteyn JC, Van Den EH, Klis FM: Cell wall dynamics in yeast. Curr Opin Microbiol 1999, 2:348-352.

3. Klis FM, Mol P, Hellingwerf $K$, Brul S: Dynamics of cell wall structure in Saccharomyces cerevisiae. FEMS Microbiol Rev 2002, 26:239-256.

4. Kollár R, Reinhold BB, Petráková E, Yeh HJ, Ashwell G, Drgonová J, Kapteyn JC, Klis FM, Cabib E: Architecture of the yeast cell wall. $\beta-1,6-$ glucan interconnects mannoprotein, $\beta-1,3-$ glucan, and chitin. J Biol Chem 1997, 272:17762-17775.

5. Cabib E, Durán A: Synthase III-dependent chitin is bound to different acceptors depending on location on the cell wall of budding yeast. J Biol Chem 2005, 280:9170-9.

6. Cappellaro C, Mrsa V, Tanner W: New potential cell wall glucanases of Saccharomyces cerevisiae and their involvement in mating. J Bacteriol 1998, 180:5030-7.

7. Mrsa V, Ecker M, Strahl-Bolsinger S, Nimtz M, Lehle L, Tanner W: Deletion of new covalently linked cell wall glycoproteins alters the electrophoretic mobility of phosphorylated wall components of Saccharomyces cerevisiae. J Bacteriol 1999, 181:3076-3086.

8. Ecker M, Deutzmann R, Lehle L, Mrsa V, Tanner W: Pir proteins of Saccharomyces cerevisiae are attached to $\beta$-1,3-glucan by a new proteincarbohydrate linkage. J Biol Chem 2006, 281:11523-11529.

9. De Groot PW, Hellingwerf K, Klis FM: Genome-wide identification of fungal GPI proteins. Yeast 2003, 20:781-796.

10. Yin QY, de Groot PW, de Jong L, Klis FM, De Koster CG: Mass spectrometric quantitation of covalently bound cell wall proteins in Saccharomyces cerevisiae. FEMS Yeast Res 2007, 7:887-96.

11. Ragni E, Sipiczki M, Strahl S: Characterization of Ccw12p, a major key player in cell wall stability of Saccharomyces cerevisiae. Yeast 2007, 24:309-19.

12. Hagen I, Ecker M, Lagorce A, Francois JM, Sestak S, Rachel R, Grossmann G, Hauser NC, Hoheisel JD, Tanner W, Strahl S: Sed1p and Srl1p are required to compensate for cell wall instability in Saccharomyces cerevisiae mutants defective in multiple GPI-anchored mannoproteins. $\mathrm{Mol}$ Microbiol 2004, 52:1413-1425.
13. Shankarnarayan S, Malone CL, Deschenes RJ, Fassler JS: Modulation of yeast $\operatorname{Sin} 1$ kinase activity by the CCW12 cell wall protein. $J$ Biol Chem 2008, 283:1962-73.

14. Cabib E, Blanco N, Grau C, Rodríguez-Peña JM, Arroyo J: Crh1p and Crh2p are required for the cross-linking of chitin to beta(1-6)glucan in the Saccharomyces cerevisiae cell wall. Mol Microbiol 2007, 63:921-35.

15. Lagorce A, Hauser NC, Labourdette D, Rodriguez C, Martin-Yken H, Arroyo J, Hoheisel JD, Francois J: Genome-wide analysis of the response to cell wall mutations in the yeast Saccharomyces cerevisiae. J Biol Chem 2003, 278:20345-20357.

16. García R, Bermejo C, Grau C, Pérez R, Rodríguez-Peña JM, Francois J, Nombela C, Arroyo J: The global transcriptional response to transient cell wall damage in Saccharomyces cerevisiae and its regulation by the cell integrity signalling pathway. J Biol Chem 2004, 279:15183-95.

17. Boorsma A, de Nobel $H$, ter Riet B, Bargmann B, Brul S, Hellingwerf $K$, Klis FM: Characterization of the transcriptional response to cell wall stress in Saccharomyces cerevisiae. Yeast 2004, 21:413-27.

18. Jung US, Levin DE: Genome-wide analysis of gene expression regulated by the yeast cell wall integrity signalling pathway. Mol Microbiol 1999, 34:1049-1057.

19. De Groot PW, Ruiz C, Vazquez de Aldana C, Dueñas E, Cid V, Del Rey F, Rodríguez Peña JM, Pérez P, Andel A, Caubín J, Arroyo J, García JC, Gil C, Molina M, García L, Nombela C, Klis FM: A genomic approach for the identification and classification of genes involved in cell wall formation and its regulation in Saccharomyces cerevisiae. Comp Funct Genom 2001, 2:124-142.

20. Zu T, Verna J, Ballester R: Mutations in WSC genes for putative stress receptors result in sensitivity to multiple stress conditions and impairment of RIm1-dependent gene expression in Saccharomyces cerevisiae. Mol Genet Genomics 2001, 266:142-155.

21. Rajavel M, Philip B, Buehrer BM, Errede B, Levin DE: Mid2 is a putative sensor for cell integrity signaling in Saccharomyces cerevisiae. Mol Cell Biol 1999, 19:3969-3976.

22. Parrish WR, Stefan CJ, Emr SD: Ptdlns(3)P accumulation in triple lipidphosphatase-deletion mutants triggers lethal hyperactivation of the Rho1p/Pkc1p cell-integrity MAP kinase pathway. J Cell Sci 2005, 118:5589-601.

23. Levin DE: Cell wall integrity signalling in Saccharomyces cerevisiae. Microbiol Mol Biol Rev 2005, 69:262-91, Review.

24. Valdivieso MH, Ferrario L, Vai M, Duran A, Popolo L: Chitin synthesis in a gas1 mutant of Saccharomyces cerevisiae. J Bacteriol 2000, 182:4752-7.

25. Bulawa CE: Genetics and molecular biology of chitin synthesis in fungi. Annu Rev Microbiol 1993, 47:505-34, Review.

26. Carotti C, Ferrario L, Roncero C, Valdivieso MH, Duran A, Popolo L: Maintenance of cell integrity in the gas 1 mutant of Saccharomyces cerevisiae requires the Chs3p-targeting and activation pathway and involves an unusual Chs3p localization. Yeast 2002, 19:1113-24.

27. Tong AH, Evangelista M, Parsons AB, Xu H, Bader GD, Pagé N, Robinson M, Raghibizadeh S, Hogue CW, Bussey H, Andrews B, Tyers M, Boone C: Systematic genetic analysis with ordered arrays of yeast deletion mutants. Science 2001, 294:2364-8.

28. Tong AH, Lesage $G$, Bader $G D$, Ding $H, X u H$, Xin $X$, Young J, Berriz GF, Brost RL, Chang M, Chen Y, Cheng X, Chua G, Friesen H, Goldberg DS, Haynes J, Humphries C, He G, Hussein S, Ke L, Krogan N, Li Z, Levinson JN, Lu H, Ménard P, Munyana C, Parsons AB, Ryan O, Tonikian R, Roberts T, Sdicu AM, Shapiro J, Sheikh B, Suter B, Wong SL, Zhang LV, Zhu H, Burd CG, Munro S, Sander C, Rine J, Greenblatt J, Peter M, Bretscher A, Bell G, Roth FP, Brown GW, Andrews B, Bussey H, Boone C: Global mapping of the yeast genetic network. Science 2004, 303:808-813.

29. Green R, Lesage G, Sdicu AM, Ménard P, Bussey H: A synthetic analysis of the Saccharomyces cerevisiae stress sensor Mid2p, and identification of a Mid2p-interacting protein, Zeo1p, that modulates the PKC1-MPK1 cell integrity pathway. Microbiology 2003, 149:2487-99.

30. Lesage G, Sdicu AM, Ménard P, Shapiro J, Hussein S, Bussey H: Analysis of beta-1,3-glucan assembly in Saccharomyces cerevisiae using a synthetic interaction network and altered sensitivity to caspofungin. Genetics 2004, 167:35-49.

31. Costanzo M, Baryshnikova A, Bellay J, Kim Y, Spear ED, Sevier CS, Ding H, Koh JL, Toufighi K, Mostafavi S, Prinz J, St Onge RP, VanderSluis B, Makhnevych T, Vizeacoumar FJ, Alizadeh S, Bahr S, Brost RL, Chen Y, Cokol M, Deshpande R, Li Z, Lin ZY, Liang W, Marback M, Paw J, San 
Luis BJ, Shuteriqi E, Tong AH, van Dyk N, Wallace IM, Whitney JA, Weirauch MT, Zhong G, Zhu H, Houry WA, Brudno M, Ragibizadeh S, Papp B, Pál C, Roth FP, Giaever G, Nislow C, Troyanskaya OG, Bussey H, Bader GD, Gingras AC, Morris QD, Kim PM, Kaiser CA, Myers CL, Andrews BJ, Boone C: The genetic landscape of a cell. Science 2010, 327:425-31.

32. Trilla JA, COS T, Duran A, Roncero C: Characterization of CHS4 (CAL2), a gene of Saccharomyces cerevisiae involved in chitin biosynthesis and allelic to SKT5 and CSD4. Yeast 1997, 13:795-807.

33. DeMarini DJ, Adams AE, Fares H, De Virgilio C, Valle G, Chuang JS, Pringle JR: A septin-based hierarchy of proteins required for localized deposition of chitin in the Saccharomyces cerevisiae cell wall. I Cell Biol 1997, 139:75-93

34. Santos B, Snyder M: Targeting of chitin synthase 3 to polarized growth sites in yeast requires Chs5p and Myo2p. J Cell Biol 1997, 136:95-110.

35. Trilla JA, Durán $A$, Roncero $C: C h s 7 p$, a new protein involved in the control of protein export from the endoplasmic reticulum that is specifically engaged in the regulation of chitin synthesis in Saccharomyces cerevisiae. J Cell Biol 1999, 145:1153-63.

36. Lagorce A, Le Berre-Anton V, Aguilar-Uscanga B, Martin-Yken H, Dagkessamanskaia A, François J: Involvement of GFA1, which encodes glutamine-fructose-6-phosphate amidotransferase, in the activation of the chitin synthesis pathway in response to cell-wall defects in Saccharomyces cerevisiae. Eur J Biochem 2002, 269:1697-707.

37. Lam KK, Davey M, Sun B, Roth AF, Davis NG, Conibear E: Palmitoylation by the DHHC protein Pfa4 regulates the ER exit of Chs3. J Cell Biol 2006, 174:19-25

38. Schmidt M, Strenk ME, Boyer MP, Fritsch BJ: Importance of cell wall mannoproteins for septum formation in Saccharomyces cerevisiae. Yeast 2005, 22:715-23.

39. Kojima H, Hashimoto H, Yoda K: Interaction among the subunits of Golgi membrane mannosyltransferase complexes of the yeast Saccharomyces cerevisiae. Biosci Biotechnol Biochem 1999, 63:1970-6.

40. Bermejo C, Rodríguez E, García R, Rodríguez-Peña JM, Rodríguez de la Concepción ML, Rivas C, Arias P, Nombela C, Posas F, Arroyo J: The sequential activation of the yeast HOG and SLT2 pathways is required for cell survival to cell wall stress. Mol Biol Cell 2008, 19:1113-24.

41. García R, Rodríguez-Peña JM, Bermejo C, Nombela C, Arroyo J: The high osmotic response and cell wall integrity pathways cooperate to regulate transcriptional responses to zymolyase-induced cell wall stress in Saccharomyces cerevisiae. J Biol Chem 2009, 284:10901-11.

42. Piao HL, Machado IM, Payne GS: NPFXD-mediated endocytosis is required for polarity and function of a yeast cell wall stress sensor. Mol Biol Cell 2007, 18:57-65

43. Huttenhower C, Myers CL, Hibbs MA, Troyanskaya OG: Computational analysis of the yeast proteome: understanding and exploiting functional specificity in genomic data. Methods Mol Biol 2009, 548:273-93.

44. Smits GJ, van den Ende H, Klis FM: Differential regulation of cell wall biogenesis during growth and development in yeast. Microbiology 2001, 147:781-794.

45. Heinisch JJ, Lorberg A, Schmitz HP, Jacoby JJ: The protein kinase Cmediated MAP kinase pathway involved in the maintenance of cellular integrity in Saccharomyces cerevisiae. Mol Microbiol 1999, 32:671-80

46. Rep M, Krantz M, Thevelein JM, Hohmann S: The transcriptional response of Saccharomyces cerevisiae to osmotic shock. Hot1p and Msn2p/Msn4p are required for the induction of subsets of high osmolarity glycerol pathway-dependent genes. J Biol Chem 2000, 275:8290-300.

47. Roberts CJ, Nelson B, Marton MJ, Stoughton R, Meyer MR, Bennett HA, He YD, Dai H, Walker WL, Hughes TR, Tyers M, Boone C, Friend SH: Signaling and circuitry of multiple MAPK pathways revealed by a matrix of global gene expression profiles. Science 2000, 287:873-80.

48. Brown JL, Bussey $\mathrm{H}$ : The yeast KRE9 gene encodes an $\mathrm{O}$ glycoprotein involved in cell surface beta-glucan assembly. Mol Cell Biol 1993, 13:6346-56.

49. Gagnon-Arsenault I, Tremblay J, Bourbonnais Y: Fungal yapsins and cell wall: a unique family of aspartic peptidases for a distinctive cellular function. FEMS Yeast Res 2006, 6:966-78.

50. Burke J, Lipari F, Igdoura S, Herscovics A: The Saccharomyces cerevisiae processing alpha 1,2-mannosidase is localized in the endoplasmic reticulum, independently of known retrieval motifs. Eur J Cell Biol 1996, 70:298-305.
51. Herscovics A, Orlean P: Glycoprotein biosynthesis in yeast. FASEB J 1993, 7:540-50.

52. Protchenko O, Rodriguez-Suarez R, Androphy R, Bussey H, Philpott CC: A screen for genes of heme uptake identifies the FLC family required for import of FAD into the endoplasmic reticulum. J Biol Chem 2006, 281:21445-57.

53. Hughes TR, Marton MJ, Jones AR, Roberts CJ, Stoughton R, Armour CD, Bennett HA, Coffey E, Dai H, He YD, Kidd MJ, King AM, Meyer MR, Slade D, Lum PY, Stepaniants SB, Shoemaker DD, Gachotte D, Chakraburtty K, Simon J, Bard M, Friend SH: Functional discovery via a compendium of expression profiles. Cell 2000, 102:109-26.

54. Watanabe M, Watanabe D, Nogami S, Morishita S, Ohya Y: Comprehensive and quantitative analysis of yeast deletion mutants defective in apical and isotropic bud growth. Curr Genet 2009, 55:365-80.

55. Delley PA, Hall MN: Cell wall stress depolarizes cell growth via hyperactivation of RHO1. J Cell Biol 1999, 147:163-74.

56. Arkowitz RA: Responding to attraction: chemotaxis and chemotropism in Dictyostelium and yeast. Trends Cell Biol 1999, 9:20-7.

57. Chant J: Cell polarity in yeast. Annu Rev Cell Dev Biol 1999, 15:365-91.

58. Trueheart J, Fink GR: The yeast cell fusion protein FUS1 is O-glycosylated and spans the plasma membrane. Proc Natl Acad SCi USA 1989, 86:9916-20.

59. Hutzler F, Gerstl R, Lommel M, Strahl S: Protein N-glycosylation determines functionality of the Saccharomyces cerevisiae cell wall integrity sensor Mid2p. Mol Microbiol 2008, 68:1438-49.

60. Lesage G, Shapiro J, Specht CA, Sdicu AM, Ménard P, Hussein S, Tong AH, Boone C, Bussey H: An interactional network of genes involved in chitin synthesis in Saccharomyces cerevisiae. BMC Genet 2005, 16:8.

61. Sheikh-Hamad D, Gustin MC: MAP kinases and the adaptive response to hypertonicity: functional preservation from yeast to mammals. Am J Physiol Renal Physiol 2004, 287:1102-10.

62. Zhan XL, Deschenes RJ, Guan KL: Differential regulation of FUS3 MAP kinase by tyrosine-specific phosphatases PTP2/PTP3 and dual-specificity phosphatase MSG5 in Saccharomyces cerevisiae. Genes Dev 1997, 11:1690-702.

63. Leza MA, Elion EA: POG1, a novel yeast gene, promotes recovery from pheromone arrest via the G1 cyclin CLN2. Genetics 1999, 151:531-43.

64. Madden K, Sheu YJ, Baetz K, Andrews B, Snyder M: SBF cell cycle regulator as a target of the yeast PKC-MAP kinase pathway. Science 1997, 275:1781-4

65. Hadwiger JA, Wittenberg C, Richardson HE, de Barros Lopes M, Reed SI: A family of cyclin homologs that control the G1 phase in yeast. Proc Natl Acad Sci USA 1989, 86:6255-9.

66. Oehlen LJ, Cross FR: G1 cyclins CLN1 and CLN2 repress the mating factor response pathway at Start in the yeast cell cycle. Genes Dev 1994, 8:1058-70.

67. Sambrook J, Fitsch EF, Maniatis T: Molecular Cloning: A Laboratory Manual Cold Spring Harbor: Cold Spring Harbor Press; 1989.

68. Robinson JS, Klionsky DJ, Banta LM, Emr SD: Protein sorting in Saccharomyces cerevisiae: isolation of mutants defective in the delivery and processing of multiple vacuolar hydrolases. Mol Cell Biol 1988, 8:4936-4948.

69. Brachmann CB, Davies A, Cost GJ, Caputo E, Li J, Hieter P, Boeke JD: Designer deletion strains derived from Saccharomyces cerevisiae S288C: a useful set of strains and plasmids for PCR-mediated gene disruption and other applications. Yeast 1998, 14:115-32.

70. Rothstein RJ: One-step gene disruption in yeast. Methods Enzymol 1983, 101:202-11.

71. Schmitt R, Sandermann H Jr: Biochemical response of Norway spruce (Picea abies (L.) karst.) towards 14-month exposure to ozone and acid mist: part II-Effects on protein biosynthesis. Environ Pollut 1990, 64:367-73.

72. Wood V, Gwilliam R, Rajandream MA, Lyne M, Lyne R, Stewart A, Sgouros J, Peat N, Hayles J, Baker S, Basham D, Bowman S, Brooks K, Brown D, Brown S, Chillingworth T, Churcher C, Collins M, Connor R, Cronin A, Davis P, Feltwell T, Fraser A, Gentles S, Goble A, Hamlin N, Harris D, Hidalgo J, Hodgson G, Holroyd S, Hornsby T, Howarth S, Huckle EJ, Hunt S, Jagels K, James K, Jones L, Jones M, Leather S, McDonald S, McLean J, Mooney P, Moule S, Mungall K, Murphy L, Niblett D, Odell C, Oliver K, O'Neil S, Pearson D, Quail MA, Rabbinowitsch E, Rutherford K, Rutter S, Saunders D, Seeger K, Sharp S, Skelton J, Simmonds M, Squares R, 
Squares S, Stevens K, Taylor K, Taylor RG, Tivey A, Walsh S, Warren T, Whitehead S, Woodward J, Volckaert G, Aert R, Robben J, Grymonprez B,

Weltjens I, Vanstreels E, Rieger M, Schäfer M, Müller-Auer S, Gabel C, Fuchs M, Düsterhöft A, Fritzc C, Holzer E, Moestl D, Hilbert H, Borzym K, Langer I, Beck A, Lehrach H, Reinhardt R, Pohl TM, Eger P, Zimmermann W, Wedler H, Wambutt R, Purnelle B, Goffeau A, Cadieu E, Dréano S, Gloux S, Lelaure V, Mottier S, Galibert F, Aves SJ, Xiang Z, Hunt C, Moore K

Hurst SM, Lucas M, Rochet M, Gaillardin C, Tallada VA, Garzon A, Thode G, Daga RR, Cruzado L, Jimenez J, Sánchez M, del Rey F, Benito J,

Domínguez A, Revuelta JL, Moreno S, Armstrong J, Forsburg SL, Cerutti L, Lowe T, McCombie WR, Paulsen I, Potashkin J, Shpakovski GV, Ussery D,

Barrell BG, Nurse P: The genome sequence of Schizosaccharomyces pombe. Nature 2002, 415:871-80.

73. Saeed Al, Sharov V, White J, Li J, Liang W, Bhagabati N, Braisted J, Klapa M, Currier T, Thiagarajan M, Sturn A, Snuffin M, Rezantsev A, Popov D, Ryltsov A, Kostukovich E, Borisovsky I, Liu Z, Vinsavich A, Trush V, Quackenbush J: TM4: a free, open-source system for microarray data management and analysis. Biotechniques 2003, 34:374-8

74. lida H, Yagawa Y, Anraku Y: Essential role for induced $\mathrm{Ca}^{2+}$ influx followed by $\left[\mathrm{Ca}^{2+}\right]$ i rise in maintaining viability of yeast cells late in the mating pheromone response pathway. A study of $\left[\mathrm{Ca}^{2+}\right] \mathrm{i}$ in single Saccharomyces cerevisiae cells with imaging of fura-2. J Biol Chem 1990, 265:13391-13399.

doi:10.1186/1471-2164-12-107

Cite this article as: Ragni et al:: The genetic interaction network of CCW12, a Saccharomyces cerevisiae gene required for cell wall integrity during budding and formation of mating projections. BMC Genomics 2011 12:107.

\section{Submit your next manuscript to BioMed Central and take full advantage of:}

- Convenient online submission

- Thorough peer review

- No space constraints or color figure charges

- Immediate publication on acceptance

- Inclusion in PubMed, CAS, Scopus and Google Scholar

- Research which is freely available for redistribution

Submit your manuscript at www.biomedcentral.com/submit 